\title{
La D.G.R.N. en su labor de toma en consideración de la ley extranjera: análisis de la práctica existente y expectativas ante la Ley 54/2007, de 28 de diciembre, de adopción internacional
}

\author{
Javier Maseda Rodríguez \\ Profesor Titular de Derecho internacional privado \\ Universidad de Santiago de Compostela
}

Recibido: 18.01 .2011

Aceptado: 30.03 .2011

\begin{abstract}
Resumen: En el ámbito del Derecho internacional privado, este trabajo tiene por objeto identificar aquellas pautas de comportamiento propias de la Dirección General de Registros y del Notariado cuando se enfrenta a la aplicación de una ley extranjera en el marco de sus resoluciones relativas a adopción internacional. Ello incluye el análisis, por una parte, del tratamiento que el Derecho extranjero recibe en este ámbito por parte de una autoridad no judicial, esto es, el quién, el cómo y con qué valor se aporta el Derecho extranjero, como, por otra, sus diferencias con la práctica jurisdiccional ordinaria. Y todo ello, y al margen de la normativa convencional vigente, ante la entrada en vigor de la Ley 54/2007, de 28 de diciembre, de adopción internacional, como normativa autónoma reguladora de esta materia en el ordenamiento jurídico español.
\end{abstract}

Palabras clave: Aplicación del Derecho extranjero.- Autoridades no judiciales: Dirección General de Registros y del Notariado.- Adopción internacional.

Abstract: In the scope of Private International Law, this paper analyses those relevant elements that allow to identify the general lines of the behaviour of the Dirección General de Registros y del Notariado in relationship with the application of foreign law in its resolutions related to international children adoption. On one hand, it will be analysed the treatment of foreign law in this matter by a non-judicial authority, that is to say, who, how and with what scope foreign law is pleaded and proved, showing, on the other hand, its differences with the court practice. And all of this, despite the Conventions rules, before the coming into force of the Spanish Ley 54/2007, de 28 de diciembre, de adopción internacional, as domestic Spanish Law regulating this subject.

Keywords: Application of foreign law.- Non-judicial authorities: Dirección General de Registros y del Notariado.- International children adoption.

Sumario: I.- INTRODUCCIÓN: EL TRATAMIENTO DE LA LEY EXTRANJERA EN LAS RESOLUCIONES DE LA D.G.R.N. RELATIVAS A ADOPCIÓN INTERNACIONAL. ESPECIAL REFERENCIA A LA LEY 54/2007, DE 28 DE DICIEMBRE, DE ADOPCIÓN INTERNACIONAL. 1.- La D.G.R.N. y su aproximación a la ley extranjera: la nueva Ley 54/2007, de 28 de diciembre, de adopción internacional. 2.La problemática relativa a la aplicación judicial y extrajudicial del Derecho extranjero: la incomodidad de la aplicación de una ley extranjera. II.LA D.G.R.N. FRENTE AL DERECHO EXTRANJERO EN MATERIA DE ADOPCIÓN 
INTERNACIONAL: UBICACIÓN DE LA PROBLEMÁTICA. 1.- Sede normativa: variedad de ubicaciones. 2.- Sede práctica. III.- OBSERVACIONES A LA LABOR DE LA D.G.R.N. EN SU ENFRENTAMIENTO CON EL DERECHO EXTRANJERO: APLICACIÓN VERSUS TOMA EN CONSIDERACIÓN. IV.- LA TOMA EN CONSIDERACIÓN DE LA LEY EXTRANJERA EN LAS RESOLUCIONES SOBRE ADOPCIÓN INTERNACIONAL: TRATAMIENTO. 1.- La carga de la aportación del Derecho extranjero. A.D.G.R.N.; Juez Encargado del Registro; Ministerio Fiscal; parte interesada. B.- El papel de la D.G.R.N. en la aportación del Derecho extranjero: desarrollo. 2.- Medios de aportación del Derecho extranjero: flexibilidad. 3.- Valoración de la ley extranjera por parte de la D.G.R.N.A.- Alcance e interpretación de la ley extranjera. B.- Contenido de la ley extranjera. V.LA NO DETERMINACIÓN DE LA LEY EXTRANJERA: CONSECUENCIAS. 1.- Posibilidad de no conocimiento. 2.- Denegación de la solicitud de inscripción. VI.- CONCLUSIONES: ALGUNAS CONSIDERACIONES TRAS LA LEY 54/2007, DE 28 DE DICIEMBRE, DE ADOPCIÓN INTERNACIONAL. 1.- Línea continuista. 2.- Expectativas de futuro.

\section{Introducción: el tratamiento de la ley extranjera en las resoluciones de la D.G.R.N. relativas a adopción internacional. Especial referencia a la Ley 54/2007, de 28 de diciembre, de adopción internacional}

1. La D.G.R.N. y su aproximación a la ley extranjera: la nueva Ley 54/2007, de 28 de diciembre, de adopción internacional

En el ámbito de la disciplina del Derecho internacional privado (D.i.pr.) y dentro del sector de la aplicación del Derecho extranjero, este trabajo tiene por objeto, fundamentalmente, identificar aquellas pautas de comportamiento propias de la Dirección General de Registros y del Notariado (D.G.R.N.) cuando se enfrenta a la aplicación de una ley extranjera en el marco de sus resoluciones relativas a adopción internacional, poniendo de manifiesto tanto el tratamiento que el Derecho extranjero recibe en esta sede, cuanto sus diferencias con la práctica jurisdiccional ordinaria. Más en concreto, los rasgos característicos relativos a cuestiones tales como cuáles son las sedes en las que se requiere la consulta de la ley extranjera, quién se encarga de aportarla, cómo proceder a su averiguación, o cuál debe ser el comportamiento de la autoridad en caso de desconocimiento del contenido de la normativa extranjera. Y ello, y al margen de la normativa convencional vigente, ante la entrada en vigor de la Ley 54/2007, de 28 de diciembre, de adopción internacional (LAI 2007), como normativa autónoma reguladora de esta materia ${ }^{1}$; y dentro de un contexto, el del Registro Civil, en el que puede observarse una cada vez más habitual obligación de aplicar una ley extranjera, debido, fundamental-

1. Ley 54/2007, de 28 de diciembre, de adopción internacional (Boletín Oficial del Estado, 29 de diciembre de 2007). 
mente, a la mayor heterogeneidad social, el incremento de la movilidad del individuo, o el aumento de las migraciones ${ }^{2}$.

Con este objetivo se procederá al análisis de la práctica actual derivada de las resoluciones de la D.G.R.N. en materia de adopción internacional existente hasta el momento, necesaria en orden a identificar estas pautas de comportamiento de la D.G.R.N. respecto de la ley extranjera propias de esta sede. Sobre ello, dos puntualizaciones. Por una parte, hay que tener en cuenta que la mayoría de las resoluciones examinadas hace referencia a la normativa anterior a la Ley 54/2007, de 28 de diciembre, de Adopción Internacional, esto es, expedientes nacidos bajo el amparo de la regulación anterior, resueltos bajo sus normas, en ausencia de disposiciones transitorias específicas de la nueva Ley, siendo mucho menor el número de resoluciones examinadas que han nacido al amparo de la normativa actual ${ }^{3}$.

Por otra parte, aun siendo así, esto es, aun cuando mucha de la práctica analizada hasta el momento se refiere, como decíamos, a la regulación anterior, entendemos la utilidad de su análisis respecto de lo que son las resoluciones de la D.G.R.N. que se hallen sujetas a la Ley 54/2007, de 28 de diciembre, de Adopción Internacional: a nuestro juicio, las conclusiones a las que llegaremos, como veremos, aun extraídas teniendo en cuenta también esta práctica anterior a la nueva Ley, resultan perfectamente trasladables a las adopciones que se hallan sometidas a la Ley 54/2007, de 28 de diciembre, de adopción internacional, salvo que las actuaciones de la D.G.R.N. desarrollando la nueva Ley evolucionen en otro sentido. Esta línea de continuidad es la que parece verse en muchas de las resoluciones de la D.G.R.N. de los últimos años, en las que, aunque se resuelven de acuerdo con la normativa anterior dado que el expediente se había iniciado antes de la entrada en vigor de la nueva Ley ${ }^{4}$, la D.G.R.N. viene introduciendo la nueva regulación especulando con lo que, en hipótesis, sería su aplicación de regular el caso, y ello para concluir de modo semejante a como ya lo había hecho. Lo vemos, por

\footnotetext{
${ }^{2}$ Sobre este incremento de situaciones, LóPEZ-BERMEJo MuÑoz, J., "Evolución estadística de la inmigración y repercusión en el Registro Civil", en Registro Civil: incidencia del fenómeno de la inmigración, Cuadernos de Derecho Civil, 2004, pp. 83-132, espec. pp. 88 y 92-95; Blanco-Morales Limones, P./Caballud Hernando, A., "Inmigración y Registro Civil”, B.I.M.J., núm. 2059, 2008, pp. 1271-1299, espec. pp. 1272 y 1298-1299.

${ }^{3}$ Se han analizado alrededor de doscientas resoluciones de la D.G.R.N. de los últimos años hasta las últimas publicadas, inclusive. Pueden encontrarse bien en la versión escrita del Boletín de Información del Ministerio de Justicia (B.I.M.J.), bien en su versión electrónica, así como en los compendios de resoluciones de la D.G.R.N. que aparecen en la página web del Ministerio de Justicia.

${ }^{4}$ En la Res. DGRN de 1 de diciembre de 2008, sobre inscripción de adopción, la D.G.R.N. indica que "...el objeto del presente recurso... ha de ser examinado a la luz de la legislación vigente a su fecha, anterior a la promulgación y entrada en vigor de la Ley 54/2007, de 28 de diciembre, de Adopción Internacional...".
} 
ejemplo, en la Res. DGRN de 21 de octubre de 2008, sobre inscripción de adopción, en la que la D.G.R.N. denegó la inscripción de una adopción guatemalteca por ausencia de equivalencia de efectos, indicando que “...con la vigente Ley 54/2007, de Adopción Internacional (que ha modificado el artículo 9 Código Civil) tampoco sería posible la estimación del recurso..."5. Y es lo que puede observarse, asimismo, y por otro lado, en las resoluciones resueltas al amparo ya de la nueva Ley, en las que se vienen reproduciendo los términos empleados hasta el momento por la D.G.R.N. cuando se enfrenta a una ley extranjera, tal como sucede, por ejemplo, en la Res. DGRN de $26 \mathrm{de} f e-$ brero de 2010, de adopción internacional.

Las razones de ello pueden tener que ver, a nuestro entender, no sólo en el hecho de que la nueva Ley no dice nada sobre la aplicación del Derecho extranjero en esta materia, sino también porque la nueva Ley sigue planteando la aplicación del Derecho extranjero, fundamentalmente y salvo algunas variantes, en las mismas sedes que la regulación anterior. Con todo, aunque esto sea así, creemos también que las novedades y modificaciones que la nueva Ley 54/2007, de 28 de diciembre, de adopción internacional ha introducido en la regulación de la adopción van a exigir un mayor esfuerzo de la D.G.R.N., además del Ministerio Fiscal, los interesados o el Juez Encargado del Registro, respecto de lo que es la toma en consideración de la ley extranjera en esta materia.

En fin, de acuerdo con lo expuesto, veremos, en un primer momento, cuáles son las sedes en las que, desde el punto de vista de la práctica analizada, la D.G.R.N. plantea el problema de la toma en consideración de la ley extranjera. Más tarde, y una vez situada la cuestión y descrito su carácter, se analizarán las cuestiones relativas a la carga de la aportación de la ley extranjera, medios de aportación, valoración del alcance e interpretación del tenor de la ley extranjera aportada, así como el comportamiento de la D.G.R.N. en caso de desconocimiento del contenido de la normativa extranjera de adopción. Terminaremos, finalmente, con unas breves conclusiones sobre este tema, que serán valoradas dentro del contexto más general de la aplicación extrajudicial del Derecho extranjero. Y todo ello, no sin antes realizar una serie de observaciones sobre el contexto en el que se mueven las autoridades no judiciales en lo que a la aplicación de una ley extranjera se refiere, relevante en tanto en cuanto estamos hablando de un órgano como la D.G.R.N.

5. Véase, asimismo, Res. DGRN (núm. 2) de 4 de enero de 2010, de adopción internacional, que menciona tanto el art. 26 LAI 2007, como el art. 9.5 Código Civil, a la hora de valorar una adopción colombiana. 


\section{La problemática relativa a la aplicación judicial y extrajudicial del Dere- cho extranjero: la incomodidad de la aplicación de una ley extranjera}

Como es sabido, el art. 12.6.1 Código Civil contempla la posibilidad que “...los Tribunales y autoridades..." apliquen una ley extranjera. Sucede con jueces y Tribunales a la hora de la valoración de una situación de tráfico externo a partir de la aplicación o toma en consideración de una ley extranjera, y sucede asimismo, en lo que ahora interesa, con autoridades no judiciales. En efecto, el legislador español contempla la posibilidad de que autoridades distintas de las judiciales, sean éstas autoridades públicas carentes de poder jurisdiccional (Notarios, Registradores, Cónsules o Diplomáticos), sean órganos detentadores de poder jurisdiccional en el ejercicio de funciones diversas (Juez encargado del Registro actuante como órgano de la Administración) ${ }^{6}$, tengan que aplicar una ley extranjera. Lo vemos, por ejemplo, con los Notarios, cuando otorgan escritura pública que afecta a personas de distinta nacionalidad, casos en los que se plantea la necesidad de aplicación de la ley nacional reguladora de la capacidad (art. 9.1 Código Civil) o cuando deben tenerse en cuenta leyes extranjeras que rigen la validez de un acto o contrato, un tema de sucesiones o la valoración del régimen económico matrimonial de una pareja; en el ámbito del Registro de la Propiedad, en relación con el reconocimiento de la fuerza registral de documentos otorgados en el extranjero, sometidos a un control de ley aplicada a la capacidad de obrar y a la forma y condiciones de la validez de un acto; o, en fin, respecto del Encargado del Registro Civil o funcionarios encargados del Registro Consular en materias como el nombre y apellidos de las personas, filiación adoptiva o por naturaleza, o matrimonio.

En cualquier caso, enfrentarse a la aplicación de una ley extranjera no es tarea sencilla. La práctica española refleja, con carácter general, la incomodidad del operador jurídico que trata con un supuesto de tráfico privado externo, y, por ende, con los recursos propios del D.i.pr. A los operadores jurídicos siempre les resultó extraña la posibilidad de resolver una controversia conforme a un ordenamiento jurídico que no fuese el propio. De ahí la bastante habitual tendencia a reconducir hacia parámetros de tráfico interno, esto es, identificar como tal, una situación que presenta contactos con varios ordenamientos. Ello les permitía valorar conforme a un ordenamiento jurídico conocido (el propio) un problema que, enfrentado de forma correcta, al

${ }^{6}$ FERnÁNDEZ RozAS, J.C., "La aplicación del Derecho extranjero por los notarios", en Conferencia pronunciada en la Academia Matritense del Notariado el día 17 de diciembre de 1994, Anales de la Academia Matritense del Notariado, tomo XXXV, Madrid, pp. 175-209, espec. p. 182; SÁNCHEZ LORENZO, S., "Algunos problemas del régimen jurídico de los actos inscribibles relativos a ciudadanos británicos", Revista Crítica de Derecho Inmobiliario, 2006, pp. 1999-2015, espec. p. 2001. 
menos, desde la óptica del D.i.pr., supondría abrir la posibilidad de aplicación de normas ajenas al mismo, por lo tanto, desconocidas ${ }^{7}$.

No contribuye precisamente a paliar esta incomodidad en el tratamiento de la ley extranjera la labor del legislador español: las autoridades judiciales y extrajudiciales se encuentran con una normativa escasa y/o no suficientemente clara, generadora de una inseguridad que la labor reciente del Tribunal Constitucional no consiguió reducir (o que sólo redujo en aspectos muy puntuales $)^{8}$. Así era, al margen de las reglas especiales que rigen la aplicación ex-

\footnotetext{
${ }^{7}$ Es lo que se ve, en el ámbito judicial, por ejemplo, en la Sent. Aud. Prov. de Barcelona (secc. 14a) de 11 de marzo de 1997 (R.G.D., 1998, p. 1302; R.E.D.I., 1998-I, p. 326, con nota de De Miguel Asensio, P.A.), donde la Audiencia Provincial resuelve la controversia relativa a un contrato de distribución internacional a través de la aplicación de la ley española, ignorando la existencia de una cláusula de sumisión a la ley italiana, que ni siquiera llega a mencionar, y desconociendo el mandato de aplicación de oficio de la norma de conflicto del art. 12.6.I. Código Civil, así como el carácter internacional del litigio. Mismo proceder parece haber en la SAP de Bizkaia de 11 de octubre de 2006 (R.E.D.I., vol. LIX, 2007-I, pp. 308314, con nota de ARENAS García, R.), en la que la Audiencia parece empeñada en utilizar todos los medios posibles para llegar a la aplicación de la ley española, aun cuando estos mismos medios le llevaban sin duda a la aplicación de la ley de Costa Rica. En esta sentencia, la Audiencia, al margen de no aplicar un Convenio que vincula a España (Convenio de Viena de 1980 sobre compraventa internacional de mercancías), aplica el art. 10.5 Código Civil, tácitamente derogado ante la vigencia en aquellos momentos del Convenio de Roma de 19 de junio de 1980 sobre ley aplicable a las obligaciones contractuales, para llegar a la aplicación del Derecho español. Y, es más, plantea la hipótesis de qué ocurriría de ser aplicado el Convenio de Roma de 1980, llegando a la misma conclusión, la aplicación del Derecho español, cosa que no sucedería de haber apreciado correctamente la prestación característica, lo que no hizo y que le hubiere conducido a la ley de Costa Rica, y de haber aplicado correctamente la cláusula de cierre del art. 4.5 Convenio de Roma 1980, que utilizó para llegar al Derecho español cuando a todas luces no era posible. Sobre este proceder de la Audiencia de Bizkaia, véase más ampliamente la nota a esta resolución de ArEnAs GARcía, R., en R.E.D.I., vol. LIX, 2007-I, pp. 308-314. Es frecuente, asimismo, observar como los operadores jurídicos se amparan en el sistema (en sus defectos, habitualmente) para justificar la aplicación de la lex fori a supuestos a priori regulados por una ley extranjera. Por ejemplo, ¿para qué sostener una interpretación del art. 12.6 Código Civil favorable a la aplicación de oficio del Derecho extranjero cuando la propia norma permite una interpretación que ampara su aplicación a instancia de parte, lo que conducirá en su defecto a la habitual aplicación del Derecho español a título subsidiario, esto es, de un Derecho conocido?. Por todas, STS de 12 de enero de 1989 (Ref. Aranzadi, 1989, n 100; R.E.D.I., 1990-I, p. 275, con nota de CHECA MARTíneZ, M.); o la STS de 23 de octubre de 1992 (Ref. Aranzadi, 1992, nº 8280; R.E.D.I., 1993-II, p. 500, con nota de MASEDA RoDRíGUEZ, J.). Muestra de esta incomodidad la vemos también en materia de competencia judicial internacional, como sucede con la STS de 11 de junio de 2003 (Ref. Aranzadi, n 5348, con comentario de MASEDA Rodríguez, J., en Anuario español D.i.pr., 2004, pp. 976-980), o Sent. Aud. Prov. de Barcelona de 13 de junio de 1989, R.E.D.I., 1990, p. 602).

${ }^{8}$ Véanse las STC 10/2000, de 17 de enero (Boletín Oficial del Estado, 18 de febrero de 2000, $\mathrm{n}^{\circ}$ 42, Suplemento); STC 155/2001, de 2 de julio; STC 33/2002, de 11 de febrero; STC 172/2004, de 18 de octubre de 2004; o la STC 29/2004, de 4 de marzo de 2004 (RTC, 2004, 29).
} 
trajudicial de la ley extranjera, la normativa general anteriormente recogida en el art. 12.6 Código Civil, y así es, sobre todo, la nacida de la reforma operada por la Ley 1/2000, de 7 de enero, de Enjuiciamiento Civil, que, si bien modificó el párrafo segundo del art. 12.6 Código Civil, transformándolo en el art. 281.2 Ley de Enjuiciamiento Civil 2000, realmente, no aporta gran cosa a la hora de aclarar el panorama9. Tal es así que, partiendo de idéntica base normativa, se llegan a observar comportamientos tan dispares como, por ejemplo, sostener la aplicación del Derecho extranjero, bien ex officio, bien la opción contraria, a instancia de parte; y todo ello, lo que es más significativo, perfectamente ajustado a la norma ${ }^{10}$.

Ahora bien, aun cuando el art. 12.6.1 Código Civil se refiera a la aplicación de la ley extranjera tanto por los Tribunales como por el resto de “....autoridades...", el panorama descrito y las expectativas difieren en uno y otro caso. A nuestro entender y a pesar del panorama referido, las autoridades judiciales se encuentran en una posición más ventajosa que las no-judiciales en lo que respecta a la aplicación de una ley extranjera. Aun cuando la normativa reguladora de la materia no es clara, los jueces y Tribunales sí encuentran más puntos de apoyo respecto a cómo moverse en el campo de su efectiva aplicación, esto es, en el cómo llegar a considerar su aplicación, en el reparto de cargas o en el cuál es la consecuencia del no-hacer o del desconocer la ley extranjera aplicable.

Cuentan, por un lado, con un amplio bagaje doctrinal que viene analizando los problemas de la materia desde antiguo, identificando problemas y aportando soluciones ${ }^{11}$. Cuentan, asimismo, con una muy abundante práctica jurisdiccional en aplicación de una ley extranjera. Piénsese que se ha hablado siempre de unos arts. 12.6 Código Civil y 281.2 Ley de Enjuiciamiento Civil

\footnotetext{
${ }^{9}$ Por todos, Fernández Rozas, J.C., "Comentario al art. 12.6 C.c.", en Comentarios al Código Civil y Compilaciones Forales, Albaladejo, M./Díaz Alabart, S., (dir.), tomo I, vol. II, Edersa, Madrid, 1995, pp. 973-1082; GarcimarTín AlfÉREZ, F.J., Sobre la norma de conflicto y su aplicación judicial, Tecnos, Madrid, 1994; JimÉnEZ BLANCO, P., "Art. 281 LEC 2000”, Ley de Enjuiciamiento Civil (Ley 1/2000), GómEZ DE LiAÑo, F., (coord.), Oviedo, 2000, pp. 348-350; Virgós Soriano, M./GarcimarTín AlfÉrez, F.J., Derecho procesal civil internacional (litigación internacional), Civitas, Madrid, 2000, pp. 365-388.

${ }^{10}$ En todo caso, la incertidumbre respecto de cómo proceder genera en ocasiones manifestaciones curiosas por parte de los operadores jurídicos españoles cuando se enfrentar a un Derecho extranjero; por ejemplo, la interpretación a contrario sensu de que "...no puede en España aplicarse de oficio la ley extranjera cuando no se alega de forma suficiente ni nadie se acoge a ella...", de la STS de 23 de octubre de 1992 (Ref.Aranzadi, 1992, n 8280; R.E.D.I., 1993-II, p. 500). Lo mismo en Sent. Aud. Prov. de Almería de 29 de noviembre de 2002, cuando estima que “...no puede en España aplicarse de oficio la ley extranjera cuando la misma no ha sido alegada suficientemente..." (si lo es, no puede hablarse de de oficio).

${ }^{11}$ Véanse los trabajos aquí referidos respecto de la aplicación de la ley extranjera por jueces y Tribunales y sus propias remisiones.
} 
2000 como preceptos deliberadamente ambiguos o de textura abierta ${ }^{12}$, una suerte de habilitación al desenvolvimiento judicial para que, en ausencia de modelo definido ${ }^{13}$, sean los propios jueces y Tribunales los que definan las líneas maestras del tratamiento procesal de una ley extranjera ${ }^{14}$ : de ahí la existencia de práctica jurisprudencial relativa a la mayoría de los problemas que se pueden plantear en proceso cuando entra en juego una ley extranjera, desde su aplicación de oficio o a instancia de parte, su objeto y medios de prueba, hasta las alternativas a la ausencia de prueba o imposible aplicación de la ley extranjera, pasando por la posibilidad de recurso por inaplicación y/o defectuosa aplicación del Derecho extranjero. Cuentan, en fin, con la labor del Tribunal Constitucional, que, a pesar de sus escasas resoluciones en la materia, cuando resolvió lo hizo precisamente en sede de aplicación judicial de una ley extranjera, sobre todo a partir de lo dispuesto en la STC 10/2000, de 17 de enero, y en la STC 155/2001, de 2 de julio, que vinculan la aplicación judicial del Derecho extranjero y la tutela judicial efectiva del art. 24.1 Constitución Española (motivación suficiente de toda resolución), y del art. 24.2 Constitución Española (desarrollo de un proceso con todas las garantías, en concreto, medios de prueba) ${ }^{15}$.

No sucede lo mismo, a nuestro juicio, en sede de aplicación extrajudicial de la ley extranjera, a pesar de que el art. 12.6.1 Código Civil, como vimos, afirme indistintamente que "...los Tribunales y autoridades aplicarán de oficio las normas de conflicto del Derecho español...": las autoridades no judiciales cuentan con menos puntos de apoyo respecto de cómo moverse en el campo de la efectiva aplicación de una ley extranjera, esto es, más dudas respecto a lo que veíamos antes de cómo llegar a considerar su aplicación, el re-

${ }^{12}$ Cortés Domínguez, V., Derecho procesal civil internacional, Madrid, 1981, p. 62; CARrillo Salcedo, J.A., “Art. 12.6 C.c.”, en Comentarios al Código Civil y Compilaciones Forales, Albaladejo, M. (dir.) Jaén, 1978, pp. 445-450, espec. p. 446; GaRcimarTín AlfÉREZ, F.J., "Nota a STS (Sala 1ª) de 17 de diciembre de 1991", R.E.D.I., 1992-I, pp. 239-243, espec. p. 241. No entiende que se esté ante un sistema de textura abierta, CARRILlo Pozo, L., "El Derecho extranjero en el proceso de trabajo", Rev. Min. Trab. y Asuntos Soc., núm. 62, 2006, pp. 13-57, espec. p. 54.

${ }^{13}$ Alvarez GonZÁLEZ, S., "Aplicación judicial del Derecho extranjero: la desconcertante práctica judicial, los estériles esfuerzos doctrinales y la necesaria reforma legislativa", $L a$ Ley, 4 de julio de 2005, pp. 1-7, con este título tan significativo.

${ }^{14}$ Virgós Soriano, M./Garcimartín Alférez, F.J., Derecho procesal civil internacional (litigación internacional), $2^{\mathrm{a}}$ ed., Civitas, Madrid, 2007, p. 520.

${ }^{15}$ Sobre la STC 10/2000, de 17 de enero de 2000, véase CARBALlo PIÑEIRO, L., "El carácter imperativo de la norma de conflicto y la prueba del Derecho extranjero. Una relectura en clave procesal y constitucional", Anuario español D.i.pr., vol. I, 2001, pp. 485-504. En general, sobre la vertiente constitucional de la aplicación judicial del Derecho extranjero, además del trabajo reseñado, véase Garcimartín Alférez, F.J., Sobre la norma de conflicto..., passim, y CuARTERo RuBio, M.V., "Prueba del Derecho extranjero y tutela judicial efectiva", Derecho Privado y Constitución, $\mathrm{n}^{\circ}$ 14, 2000, pp. 21-71. 
parto de cargas cara a su aportación, o cuáles deben ser las consecuencias del no-hacer o del desconocer la ley extranjera reclamada.

Las razones son varias. Es cierto que la aplicación del Derecho extranjero por autoridad pública que desarrolla funciones no jurisdiccionales se halla sometida a reglas especiales, de modo que las normas que rigen la aplicación judicial del Derecho extranjero, en concreto, el art. 281.2 Ley de Enjuiciamiento Civil 2000, deben ser aplicadas de manera subsidiaria, si ello es posible, en los casos de aplicación extrajudicial ${ }^{16}$. No obstante, la posición de partida de las autoridades no judiciales no es la misma que aquélla de jueces y Tribunales. Por una parte, muchas de las cuestiones que plantea la aplicación no judicial de la ley extranjera no están resueltas en las reglas especiales que el legislador ha elaborado para esta sede, y el recurso a la aplicación subsidiaria del art. 281.2 Ley de Enjuiciamiento Civil 2000 tampoco ayuda: la mayoría de los interrogantes que se plantean sobre el alcance del art. 281.2 Ley de Enjuiciamiento Civil 2000 y del art. 12.6.1 Código Civil, y que se resuelven a través de la práctica, lo hacen, como vimos, respecto de lo que es la aplicación judicial de la ley extranjera, proponiendo unas formas de comportamiento concretas que son difícilmente trasladables a la sede extrajudicial debido a las peculiaridades del medio. Lo vemos, como muestra, respecto de la cuestión de cuál debe ser el comportamiento de la autoridad no judicial en caso de imposible determinación del Derecho extranjero: la práctica jurisdiccional, desarrollando los arts. 12.6.1 Código Civil y 281.2 Ley de Enjuiciamiento Civil 2000, discurre entre la desestimación de la demanda, la aplicación de otro Derecho conectado, o, la habitual, la aplicación subsidiaria de la ley española; respuestas éstas que son escasamente útiles (por poco trasladables), por ejemplo, para la D.G.R.N. que no llega a conocer la ley extranjera que debe tomar en consideración a la hora de valorar la solicitud de inscripción de una resolución extranjera constituyendo una adopción, y que, lejos de aplicar subsidiariamente la ley española, opta, mejor, por la no inscripción de la adopción. Lo vemos, también, respecto de los medios de prueba para llegar al conocimiento de la ley extranjera: frente a la rigidez exigida en la práctica judicial, existe una mayor flexibilidad de medios en sede no judicial, lo que puede ser razonable habida cuenta de que, al tratarse de actos de administra-

\footnotetext{
${ }^{16}$ En este sentido, Fernández RozAs, J.C./SÁnchez Lorenzo, S., Derecho internacional

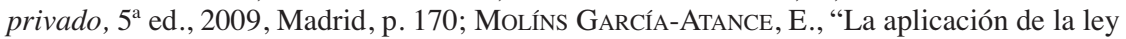
extranjera por los Tribunales españoles y la posición que debe adoptar el juez en estos procesos", en Objeto y carga de la prueba civil, Pico i JunOY, J./Abel Lluch, X., 2007, pp. 277 300 , espec. p. 295. De hecho, las autoridades no judiciales también se hallan vinculadas por las normas de aplicación que sirven de apoyo a las normas de conflicto, como puede ser el art. 12.5 Código Civil relativo a la remisión a un sistema plurilegislativo; así, SÁnchEz LoRENZO, S., "Algunos problemas del régimen jurídico...", loc. cit., p. 2003. Véase, en la práctica no judicial, la Res. DGRN de 5 de febrero de 2005.
} 
ción y no de resoluciones jurisdiccionales, siempre cabe revocabilidad por vía jurisdiccional ${ }^{17}$.

Por otra parte, y a diferencia de la sede judicial, las autoridades extrajudiciales cuentan con un menor bagaje doctrinal en el que apoyarse: la dedicación que la doctrina dispensa al tratamiento extrajudicial del Derecho extranjero resulta mucho menor si la comparamos con la perspectiva judi$\mathrm{cial}^{18}$. La mayor conflictividad que genera la aplicación judicial de una ley extranjera está detrás de ello, lo que, unido al hecho de la gran variedad de autoridades no judiciales que pueden aplicar un Derecho extranjero y los diferentes contextos en los que operan, hace que sea difícil marcar una pauta común de comportamiento en lo que son las diferentes fases por las que discurre la aplicación de una ley extranjera. Finalmente, no debe olvidarse que la práctica extrajudicial relativa a la aplicación de una ley extranjera es menos abundante que la jurisdiccional, amén de más heterogénea, y se desarrolla dentro de parámetros diferentes a los de la aplicación judicial del Derecho extranjero, al menos, en lo que es la novedad de su vertiente constitucional de tutela judicial efectiva.

En fin, teniendo en cuenta este contexto, pasemos, pues, a evaluar el comportamiento de la D.G.R.N. cuando se enfrenta a la aplicación de una ley extranjera en el marco de sus resoluciones relativas a adopción internacional.

\section{La D.G.R.N. frente al Derecho extranjero en materia de adopción in- ternacional: ubicación de la problemática}

\section{Sede normativa: variedad de ubicaciones}

Previamente al análisis del tratamiento que la D.G.R.N. depara al Derecho extranjero, debe procederse a ubicar esta problemática, esto es, resulta

17 Sobre ello, Fernández Rozas, J.C./SÁnchez Lorenzo, S., Derecho internacional..., op. cit., 2009, p. 170. A lo largo de este trabajo veremos como existen distintos aspectos en los que se pueden apreciar diferencias sustanciales en lo que es la aplicación judicial y extrajudicial de la ley extranjera. Al respecto, FERnÁndEZ RozAS, J.C., "La aplicación del Derecho extranjero por los notarios", loc. cit., p. 204; GonZÁlez CAMPOS, J.D. (et al.), Derecho internacional privado. Parte especial, Eurolex, Madrid, 1995, pp. 105-106. Más en general, RodríGuez GaYÁn, E., Derecho registral civil internacional, Eurolex, Madrid, 1995, nº 101.

${ }^{18}$ Como muestra, sobre aplicación extrajudicial del Derecho extranjero, FERNÁNDEZ RozAs, J.C., "La aplicación del Derecho extranjero por los notarios", loc. cit., pp. 175-209; FERNÁNDEZ Rozas, J.C., "Comentario al art. 12.6 C.c.”, en Comentarios..., loc. cit., pp. 10501082. Hacen referencia a esta menor dedicación doctrinal, en materia de adopción internacional, MASEDA RodRíguez, J., "La toma en consideración del Derecho extranjero por la D.G.R.N. en materia de adopción internacional", en Derecho registral internacional. Homenaje a la memoria del Profesor Rafael Arroyo Montero, Iprolex, Madrid, 2003, pp. 351-360, espec. pp. 351-352; con carácter general, FERnÁNDEZ RoZAS, J.C./SÁNCHEZ LORENZO, S., Derecho internacional..., op. cit., 2009, p. 167; AREnAS GARCÍA, R., Registro mercantil y Derecho del comercio internacional, Madrid. 2000, p. 420. 
necesario determinar la sede en la cual se suscita el problema de la aplicación de una ley extranjera en el ámbito de las resoluciones relativas a adopción internacional provenientes de este organismo. A este respecto, una lectura de la Ley 54/2007, de 28 de diciembre, de adopción internacional, como normativa reguladora de esta materia, permite identificar distintas sedes introductorias de una ley extranjera en las que, consecuentemente, la D.G.R.N. podría encontrarse con el problema relativo a su aplicación en materia de adopción.

Desde esta óptica normativa, la posibilidad de aplicación de una ley extranjera aparece fundamentalmente en sede reconocimiento de resoluciones extranjeras ${ }^{19}$. Así, como uno de los requisitos exigidos para la validez en España de adopciones constituidas por autoridades extranjeras, el art. 26.1 LAI 2007, en defecto de normas internacionales, impone el control de la ley aplicada por la autoridad competente del Estado de origen de acuerdo con las normas de conflicto del Estado del que depende la Autoridad extranjera que constituyó la adopción. Recuérdese que el anterior art. 9.5 Código Civil exigía comprobar que esta autoridad extranjera había aplicado la ley del adoptando en cuanto a capacidad y consentimientos necesarios.

Asimismo, de acuerdo con lo expuesto también en este mismo precepto, la autoridad competente del Estado de origen debe consultar el tenor de una ley extranjera a la hora de verificar si “...no se ha prestado alguna declaración de voluntad o no se ha manifestado el consentimiento exigido por la ley extranjera reguladora de la constitución de la adopción...": de ser así, esto es, en aquellos casos en los que no se haya prestado alguna de las declaraciones de voluntad o no se haya manifestado alguno de los consentimientos exigidos por la ley extranjera, dicho requisito deberá ser completado en España ante las autoridades competentes españolas con arreglo a los criterios contenidos en la Ley 54/2007, de 28 de diciembre, de adopción internacional, o bien ante cualquier otra autoridad extranjera competente.

Del mismo modo, y también dentro de las condiciones exigidas para la validez en España de adopciones constituidas por autoridades extranjeras, el art. 26.2 LAI 2007 estima que, “...cuando el adoptante o el adoptado sean españoles, la adopción constituida por autoridad extranjera debe surtir los efectos jurídicos que se corresponden, de modo sustancial, con los efectos de la adopción regulada en Derecho español...". Ello exige la consulta de la ley extranjera conforme a la cual se ha constituido la adopción a fin de controlar, en

${ }^{19}$ LARA Aguado, A., “Adopción internacional: relatividad de la equivalencia de efectos y sentido común en la interpretación del Derecho extranjero", R.E.D.I., vol. LX, 2008-I, pp. 128-145, espec. pp. 130-131; MASEDA RodrígueZ, J., "La toma en consideración del Derecho extranjero por la D.G.R.N. ...", loc. cit., p. 154; SÁNCHEZ LoRENZO, S., "Globalización, pluralidad cultural y Derecho internacional de la familia", Anuario Hispano-LusoAmericano de Derecho Internacional, núm. 17, Madrid, 2005, pp. 87-130, espec. p. 126; EsTEBAN DE LA RosA, G. (coord), Regulación de la adopción internacional (nuevos problemas, nuevas soluciones), 2007, p. 303. 
concreto, que la adopción constituida por autoridad extranjera produce “...la extinción de vínculos jurídicos sustanciales entre el adoptado y su familia anterior, que haga surgir los mismos vínculos de filiación que los de la filiación por naturaleza y que sea irrevocable por los adoptantes ..." ${ }^{20}$. Respecto de este último punto, el art. 26.2 LAI 2007 introduce de nuevo la consulta de la ley extranjera, al establecer, en particular, que, “...cuando la ley extranjera admita que la adopción constituida a su amparo pueda ser revocada por el adoptante, será requisito indispensable que éste, antes del traslado del menor a España, renuncie al ejercicio de la facultad de revocarla...": la renuncia al derecho de revocación de la adopción sólo procederá, pues, si la ley extranjera prevé la revocación, con lo que habrá que saber qué dispone la ley extranjera sobre este aspecto ${ }^{21}$.

Téngase en cuenta finalmente, en este orden de asuntos, la posibilidad de tener que llegar al conocimiento de la ley extranjera respecto de lo que son las funciones de los Cónsules españoles en el extranjero. Recuérdese que tanto la legislación anterior del art.9.5 Código Civil, como el art. 17 LAI 2007 actual, permiten al Cónsul español no sólo "...constituir adopciones, en el caso de que el adoptante sea español y el adoptando tenga su residencia habitual en la demarcación consular correspondiente...", como ejercer competencias y funciones de Encargado del Registro Civil. Ahora bien, ello será posible siempre que "...el Estado receptor no se oponga a ello, ni lo prohíba su legislación..." (art. 17 LAI 2007; art. 5.f del Convenio de Viena sobre Relaciones Consulares de 24 de abril de 1963), lo que obliga a la consulta de la ley extranjera a fin de verificar estos aspectos.

\section{Sede práctica}

Si esto es así desde un punto de vista normativo, la práctica demuestra, sin embargo, y a pesar de estas distintas situaciones en las que el operador jurídico puede enfrentarse a la aplicación de una ley extranjera, cómo el problema se suscita casi exclusivamente a la hora de ponderar la equivalencia de efectos entre la adopción constituida conforme a una normativa extranjera y lo que la normativa española entiende por adopción ${ }^{22}$. Esto es, lo que establece el anterior art. 9.5 Código Civil in fine, introducido por la Ley 1/1996, de Protección Jurídica del Menor, cuando afirmaba que "...no se reconocerá en España como adopción la constituida en el extranjero por adoptante español si

${ }^{20}$ Lara Aguado, A., “Adopción internacional...”, loc. cit., p. 131.

${ }^{21}$ LaRa Aguado, A., "Adopción internacional...", loc. cit., p. 131.

${ }^{22}$ Esteban de la Rosa, G. (coord), Regulación de la adopción internacional..., op. cit., pp. 302-303; MASEDA RodRíGUEZ, J., "La toma en consideración del Derecho extranjero por la D.G.R.N. ...", loc. cit., pp. 351-360; LARA AgUADO, A., “Adopción internacional...”, loc. cit., p. 130; Álvarez Álvarez, J.M., "El Registro Civil Central”, B.I.M.J., núm. 1834, de 1 de diciembre de 1998, pp. 3437-3464, espec. p. 3454. 
los efectos de aquélla no se corresponden con los previstos por la legislación española"; y que tiene su equivalente en el referido art. 26.2 LAI 2007, cuando establece que “...la adopción constituida por autoridad extranjera...”, para su reconocimiento como adopción, “...debe surtir los efectos jurídicos que se corresponden, de modo sustancial, con los efectos de la adopción regulada en Derecho español..."23.

Así es, por ejemplo, en la práctica más antigua de la D.G.R.N., tal como puede observarse en la Res. DGRN de 6 de mayo de 2000, sobre adopción; la Res. DGRN de 5 de abril de 2000, sobre adopción guatemalteca; la Res. DGRN de 5 de febrero de 1998, sobre inscripción de adopción nepalí; la Res. DGRN de 13 de noviembre de 1998, sobre adopción guatemalteca; o la Res. DGRN de 6 de marzo de 1997, sobre inscripción de adopción china. Y también en la práctica más reciente, como sucede, por ejemplo, con la Res.DGRN de 1 de diciembre de 2008, sobre inscripción de adopción; la Res. DGRN de 16 de febrero de 2009, sobre inscripción de adopción; la Res. DGRN de 3 de septiembre de 2009, sobre inscripción de nacimiento derivada de adopción internacional ${ }^{24}$; la Res. DGRN (núm. 1) de 4 de enero de 2010, de adopción internacional, o la Res. DGRN de 26 de febrero de 2010, de adopción internacional, estas últimas al amparo de la nueva Ley de adopción.

En el resto de sedes a las que se hacía referencia, la actuación de la D.G.R.N., y así es en su práctica más antigua y también en la actual, se identifica más con una labor de presentación de la cuestión de la aplicación de un Derecho extranjero que con un verdadero enfrentamiento directo con su problemática concreta. Sirva el anterior art. 9.5 Código Civil en su remisión a la ley nacional del adoptando como ejemplo ilustrativo de esta forma de actuar: el comportamiento habitual de la D.G.R.N. en el examen de la adopción constituida ante autoridad extranjera consiste en afirmar la aplicación efectiva de la ley del adoptando en cuanto a su capacidad y consentimiento necesarios, para detener su análisis en este punto, esto es, no llega a realizar un verdadero control del tenor de la ley aplicada. Así se ve, como muestra, en la Res. DGRN de 21 de octubre de 2008, sobre inscripción de adopción; o en la Res. DGRN de 1 de febrero de 2007, sobre inscripción de adopción etíope: en este último caso, la D.G.R.N. valora la equivalencia de efectos entre la adopción etíope y la española, después de haber “...presupuesto...”, en palabras literales de la

\footnotetext{
${ }^{23}$ LaRa Aguado, A., “Adopción internacional...”, loc. cit., p. 130, en relación con la Ley 54/2007, de 28 de diciembre, de adopción internacional.

${ }^{24}$ Res. DGRN de 6 de mayo de 2000, sobre adopción (B.I.M.J., nº 1874, p. 2676); Res. DGRN de 5 de abril de 2000, sobre adopción guatemalteca (B.I.M.J., ${ }^{\circ} 1870$, p. 2018; con nota de CAmPuZANo Díaz, B., R.E.D.I., 2000-II, p. 612); Res. DGRN de 5 de febrero de 1998, sobre inscripción de adopción nepalí (B.I.M.J., $\mathrm{n}^{\circ} 1827-1828$, p. 2158); Res. DGRN de 13 de noviembre de 1998, sobre adopción guatemalteca (B.I.M.J., $\mathrm{n}^{\circ}$ 1851-1852, p. 2550); Res. $D G R N$ de 6 de marzo de 1997, sobre inscripción de adopción china (B.I.M.J., $\mathrm{n}^{\circ} 1823$, p. 1498).
} 
D.G.R.N., que la autoridad etíope competente constituyó la adopción aplicando la ley etíope a la capacidad y consentimientos necesarios del adoptando, esto es, no se realiza un verdadero control del tenor de la ley etíope en este punto, al igual que sucede en la Res. DGRN de 16 de febrero de 2009, sobre inscripción de adopción. Este comportamiento se reproduce, asimismo, respecto del actual art. 26 LAI 2007, como puede verse en la Res. DGRN de 26 de febrero de 2010, de adopción internacional, cuando, al exigir que la adopción "...se haya constituido ante autoridad kazaja competente en la forma establecida por la lex loci y que se haya aplicado la ley designada por el ordenamiento jurídico kazajo, por ser de esta nacionalidad la autoridad que la constituyó (cfr. art. 26 de la Ley 54/2007)...”, la D.G.R.N. habla de “...presupuesto lo anterior...".

No en vano la D.G.R.N. ha adoptado a lo largo de sus resoluciones una forma de enfrentarse a este punto que, por la frecuencia de su empleo, ha adquirido una cierta carta de naturaleza. En este sentido, la fórmula que suele utilizar la D.G.R.N. es la siguiente: “...no hay duda de esta adopción se ha constituido ante las autoridades nepalíes y de que se ha aplicado la ley nacional del adoptando en cuanto a capacidad y consentimiento necesarios...". Es lo que se observa en la Res. DGRN de 14 de febrero de 1998, sobre adopción nepalí, o en la Res. DGRN de 6 de mayo de 2000, sobre adopción, y que se repite en muchas otras ${ }^{25}$.

Con todo, téngase en cuenta una serie de resoluciones que merecen destacarse por su excepcionalidad en lo que a este punto se refiere.

Por una parte, la Res. DGRN de 23 de octubre de 2009, sobre inscripción de adopción, relativa a una inscripción de nacimiento y marginal de adopción de la menor de origen nepalí adoptada en este país, que se separa de esta tendencia ya que aquí sí se valoraron efectivamente los “...requisitos de capacidad exigidos por la ley aplicable a la capacidad y consentimientos, en este caso, la ley del adoptando, conforme a lo dispuesto por el artículo 9.5 del Código Civil, vigente cuando se constituyó la adopción...”: de acuerdo con la ley nepalí, a saber, el Number 12 A del Chapter on Adoption of the Country Code (Muluki Ain), sólo se permite la adopción de menores nepalíes por parejas casadas que lleven al menos cuatro años de matrimonio, con lo que, dado que la interesada no puso en conocimiento de la autoridad nepalí que constituyó la adopción esta circunstancia esencial de su estado civil, dicha autoridad no pudo aplicar el límite de capacidad vigente en dicha legislación, por lo cual la adopción no pudo ser reconocida como válida y, por tanto, no pudo acceder al Registro Civil español por haberse constituido con vulneración de la ley estatal designada por el anterior art. 9.5 Código Civil.

${ }^{25}$ Res. DGRN de 30 de marzo de 1999, sobre adopción vietnamita (B.I.M.J., n ${ }^{\text {1856, p. }}$ 3252; R.E.D.I., 2000-I, p. 213, con nota de CAMPuZANo Díaz, B.); Res. DGRN de 6 de mayo de 2000, sobre adopción, cit.; Res. DGRN de 5 de febrero de 1998, sobre inscripción de adopción nepalí. 
Por otra, la Res. DGRN de 20 de enero de 2009, sobre inscripción de adopción (surcoreana), respecto de la inscripción de nacimiento en el Registro Civil Consular de Seúl (Corea del Sur) de un menor surcoreano adoptado por una pareja con doble nacionalidad española y australiana y residente en Australia, relevante en la medida en que sí se plantea la toma en consideración de la ley extranjera fuera de su sede habitual, la equivalencia de efectos, para plantearse dentro de lo que son las funciones de los Cónsules españoles en el extranjero (art. 17 LAI 2007; art. 5 .f del Convenio de Viena sobre Relaciones Consulares de 24 de abril de 1963): “...la aplicación de este(s) precepto(s) obliga a examinar el contenido material del Derecho propio del Estado receptor del Cónsul o Encargado consular, esto es, en el presente caso, la regulación que en materia de constitución, reconocimiento e inscripción de las adopciones existe en el Derecho de Corea del Sur...", a fin de verificar que “...el Estado receptor no se oponga a ello, ni lo prohíba su legislación...”. En parecidos términos, la Res. DGRN de 4 de septiembre de 2009, de adopción internacional, respecto de la competencia del Cónsul español para inscribir una adopción constituida por autoridad local surcoreana solicitada por un matrimonio entre española y estadounidense, respecto de la que se constata la contrariedad de esta actuación con la legislación interna de Corea del Sur.

\section{Observaciones a la labor de la D.G.R.N. en su enfrentamiento con el Derecho extranjero: aplicación versus toma en consideración}

De acuerdo con lo expuesto, la cuestión de la aplicación del Derecho extranjero por parte de la D.G.R.N. se plantea básicamente a la hora de ponderar la equivalencia de efectos entre una adopción constituida por una autoridad extranjera y lo que la normativa española entiende por adopción. En este orden de asuntos y previamente al análisis de esta labor, conviene poner de manifiesto ciertos aspectos relativos a su forma de actuar dirigidos, fundamentalmente, a procurar una más certera calificación de la tarea de la D.G.R.N. enfrentada a un Derecho extranjero.

Evidentemente, no se trata de aplicación de Derecho extranjero stricto sensu, esto es, no se trata de aparejar una consecuencia jurídica a un supuesto de hecho de una norma. A nuestro juicio, debería hablarse con mayor propiedad de toma en consideración del Derecho extranjero, en este caso, en orden a realizar la ponderación de efectos equivalentes entre adopción extranjera y española ${ }^{26}$. Todo ello, a pesar de que la D.G.R.N., a la hora de realizar esta ponderación de equivalencias, se pronuncia en numerosas ocasiones emple-

${ }^{26}$ Respecto de esta toma en consideración, CAlvo CARAVACA, A.L./CARRASCOSA GonZÁLEZ, J., Derecho de familia internacional, $2^{\mathrm{a}}$ ed., 2004, p. 315; MASEDA RodrígueZ, J., "La toma en consideración del Derecho extranjero por la D.G.R.N. ...", loc. cit., p. 354; LARA AguAdo, A., “Adopción internacional...", loc. cit., p. 131. 
ando los concretos términos de aplicación de Derecho extranjero e introduciendo en el discurso tanto aquellos preceptos identificativos de una labor propia de aplicación, como es, en concreto, el art. 12.6 Código Civil, como términos típicos de lo que es la aplicación del Derecho extranjero, como prueba o interpretación de la ley extranjera. No obstante, lo hace más como fórmula al uso que pensando en una verdadera aplicación del Derecho extranjero, ya que lo cierto es que, en sus resoluciones, la D.G.R.N. nunca llega a profundizar en la problemática propia de este precepto a pesar de que alude efectivamente a su tenor, como tampoco a realizar una labor típica de prueba del Derecho extranjero al estilo de su aplicación judicial.

Tal es lo que se observa en la fórmula empleada por la D.G.R.N. cuando establece: “...si ya la simple aplicación del Derecho extranjero plantea dificultades cuando se trata de acreditar su contenido y vigencia (confr. art. 12.6 Código Civil), es evidente que la tarea es aún más delicada cuando no sólo hay que desentrañar el alcance de una institución extranjera sino, además, efectuar una labor de comparación entre una determinada institución extranjera y la correlativa institución española..." (Res. DGRN de 14 de febrero de 1998, sobre inscripción de adopción nepali; Res. DGRN de 5 de febrero de 1998, sobre inscripción de adopción nepalí; Res. DGRN de 30 de marzo de 1999, sobre adopción vietnamita; Res. DGRN de 1 de febrero de 2007, sobre inscripción de adopción etíope; Res. DGRN de 1 de diciembre de 2008, sobre inscripción de adopción; la Res. DGRN de 16 de febrero de 2009, sobre inscripción de adopción; la Res. DGRN de 3 de septiembre de 2009, sobre inscripción de nacimiento derivada de adopción internacional; y así muchas otras) ${ }^{27}$. La misma utilización por inercia o fórmula, no descriptiva de una verdadera aproximación a la aplicación de una ley extranjera, puede decirse cuando la D.G.R.N. emplea términos como “...partiendo de la prueba del Derecho etíope disponible en tal momento...", o "...en este proceso interpretativo...", como sucede en la Res. DGRN de 1 de diciembre de 2008, sobre inscripción de adopción.

De las resoluciones que se han analizado, sólo una va más allá de la mera utilización de la fórmula al uso, y es una de las resoluciones analizadas más antiguas, aunque sigue sin entrar de lleno en los problemas propios de aplicación del Derecho extranjero. Nos referimos a la Res. DGRN de 6 de marzo de 1997, sobre adopción china, en la que se habla de que "...se plantea una cuestión sobre el contenido y vigencia del Derecho extranjero que no es oportuno decidir en este momento..." ${ }^{28}$.

\footnotetext{
${ }^{27}$ Res. DGRN de 5 de febrero de 1998, sobre inscripción de adopción nepalí. Además, Res. DGRN de 30 de marzo de 1999, sobre adopción vietnamita, o Res. DGRN de 14 de febrero de 1998, sobre adopción nepalí (B.I.M.J., n 1827-1828, p. 2184).

${ }^{28}$ Res. DGRN de 6 de marzo de 1997, sobre inscripción de adopción china.
} 
Al hilo de la valoración de la equivalencia de efectos, una observación: la labor de ponderación de equivalencias no suele efectuarse respecto del conjunto del Derecho español, sino exclusivamente respecto de la adopción tal como aparece contemplada en el Código Civil, esto es, en los términos del Derecho común ${ }^{29}$. Criticable en la medida en que existen más realidades adoptivas que la específicamente recogida en el Código civil español, dada la pluralidad legislativa característica de nuestro ordenamiento jurídico, como sucede con el Derecho de Navarra, Cataluña, o Galicia, por ejemplo ${ }^{30}$. Con todo, y a pesar de expuesto, puede verse también cómo la D.G.R.N. parece estar abriéndose poco a poco a esta realidad plural del ordenamiento jurídico español. Lo demuestra, por ejemplo, la Res. DGRN de 12 de junio de 2002, sobre inscripción de adopción internacional, en la que tiene en cuenta no sólo el Código civil español, sino los arts. 117 a 126 Código de Familia de Cataluña de 1998, para justificar la no exigencia de certificado de idoneidad respecto de la adoptando ucraniana hija del consorte del adoptante. O la Res. DGRN de 3 de abril de 2002, sobre inscripción de adopción,

\footnotetext{
${ }^{29}$ Es lo que se ve, por ejemplo, en las menos recientes Res. DGRN de 13 de noviembre de 1998, sobre adopción guatemalteca, que habla de "...si se tiene en cuenta que la adopción única que regula el Código civil español...”; o Res. DGRN de 30 de marzo de 1999, sobre adopción vietnamita, cuando habla de "...efectos jurídicos distintos de la adopción contemplada en nuestro Código civil..."; como en las más actuales Res. DGRN de 21 de febrero de 2007, sobre inscripción de adopción etíope, que habla de "...no guardaba puntos de contacto (la adopción etíope) con la adopción del C.c. español..."; o Res.DGRN de 1 de diciembre de 2008, sobre inscripción de adopción, que habla de "....si se tiene en cuenta la adopción única que regula el Código civil español...", términos que emplea asimismo la Res. DGRN de 16 de febrero de 2009, sobre inscripción de adopción. También en la Res. DGRN de 26 de febrero de 2010, de adopción internacional, ya al amparo de la nueva Ley de adopción, cuando, a la hora de valorar la equivalencia de efectos, habla de si "... se corresponden con la adopción española regulada en el Código Civil...".

${ }^{30}$ Sobre estos aspectos, ÁlvAREZ GonZÁLEZ, S., “Adopción internacional y sociedad multicultural”, Cursos de Derecho internacional privado de Vitoria Gasteiz, 1998, pp. 177-211, espec. p. 183-185. Esta actitud de la D.G.R.N. no es extraña en el ordenamiento jurídico español. Lo vemos, por ejemplo, en materia de sucesión internacional, donde se condiciona la admisión del reenvío de retorno al respeto al principio de unidad y universalidad de la sucesión propio del Derecho español, presente, a su entender, en el art. 9.8 Código Civil, cuando existen otros Derechos civiles o forales, también españoles, entre los que el principio inspirador no es éste (sobre ello, CASTELlanos Ruiz, E., Unidad vs. pluralidad legal de sucesión internacional, Granada, 2001, p. 119; Calvo CARAVACA, A.L., "Art. 9.8 C.c.", Comentarios al Código civil y Compilaciones forales, $2^{\mathrm{a}}$ ed., Madrid, 1995, pp. 350-391, p. 359; Álvarez GoNZÁLEZ, S., "Dos cuestiones de actualidad en el reciente Derecho internacional privado español de sucesiones: los derechos del cónyuge supérstite y el reenvío", Homenaje al Prof. F.J. Serrano García, Universidad de Valladolid, 2004, pp. 131-158, espec. p. 151; véase RDGRN de 18 de enero de 2005, R.E.D.I., 2005-II, p. 1023, con nota de CALVo VIDAL, I.A). Lo mismo en materia de sucesiones y excepción de orden público internacional, valorado más en función del Derecho común español, excluyendo, muchas veces por inercia, al resto de sistemas civiles o forales convivientes.
} 
en la que, a la hora de ponderar la no-equivalencia de efectos entre la adopción guatemalteca y la española, la D.G.R.N. se apoya en la "....adopción única que regula el Código civil español, como el Código de Familia catalán..."31.

\section{La toma en consideración de la ley extranjera en las resoluciones sobre adopción internacional: tratamiento}

\section{La carga de la aportación del Derecho extranjero}

\section{A. D.G.R.N.; Juez EnCARGAdo DEL Registro; Ministerio Fiscal; PARTE IN- TERESADA}

Una vez identificada la sede de esta problemática y realizadas las observaciones expuestas, veremos a continuación el tratamiento que la D.G.R.N. depara al Derecho extranjero: carga de la aportación; medios de prueba; valoración del contenido e interpretación; y casos de no determinación del contenido de la ley extranjera.

Por lo que afecta a la carga de la aportación de la ley extranjera, de las resoluciones consultadas se concluye la ausencia de una noción clara respecto de quién aporta el Derecho extranjero al caso. En este sentido, lo que parece es que es el Juez Encargado del Registro, el Ministerio Fiscal o la propia D.G.R.N. quien se encarga de ello, en una labor que podría calificarse como ex officio ${ }^{32}$. Ello se desprende de fórmulas que el Juez encargado o la D.G.R.N. emplean en sus resoluciones, y que no varían a la largo de la práctica analizada más reciente o más antigua, del estilo de "...minucioso examen del Derecho positivo etíope, con arreglo a los textos normativos de que ha adquirido nuevamente conocimiento oficial este Centro Directivo..."; "...de acuerdo con el conocimiento adquirido de la legislación china..."; "...en vista de las informaciones obtenidas sobre la legislación mexicana..."; o

\footnotetext{
${ }^{31}$ Este cambio de actitud del operador jurídico se extiende a más sectores que en adopción internacional, como en sucesión internacional, donde cierta práctica se muestra más abierta a la consideración no sólo del Derecho común, sino también del resto de Derechos convivientes (sobre ello, Álvarez GonzÁlez, S., "Dos cuestiones...”, loc. cit., p. 149, nota núm. 33; Álvarez GonZÁlez, S., "Igualdad, competencia y deslealtad en el sistema español de Derecho interregional (y en el de Derecho internacional privado)", R.E.D.I., 2001, pp. 49-74, espec. pp.60-61; véase, por ejemplo, Sent. Aud. Prov. de Tarragona de 13 de mayo de 2004, o Sent. Aud. Prov. de Alicante de 27 de febrero de 2004).

${ }^{32}$ Esteban de la Rosa, G. (coord), Regulación de la adopción internacional..., op. cit., p. 303; Calvo Caravaca, A.L./Carrascosa González, J., Derecho de familia internacional..., op. cit., 2004, p. 316, que mencionan a Juez Encargado del Registro, Ministerio Fiscal o la propia D.G.R.N.; MASEDA RodríGUEZ, J., "La toma en consideración del Derecho extranjero por la D.G.R.N. ...", loc. cit., pp. 351-360; Calvo BABío, F., Aplicación judicial del Derecho extranjero en materia de familia, Valencia, 2010, p. 68.
} 
“...según el conocimiento adquirido de dicha legislación por este Centro Directivo, el procedimiento de adopción en República Dominicana..."33.

En este orden de asuntos, significativa es la Res. DGRN de 24 de septiembre de 2002, sobre adopción ecuatoriana. El Juez Encargado del Registro denegó la inscripción de nacimiento de una menor adoptada en Ecuador por ausencia de una equivalencia de efectos entre la adopción española y la ecuatoriana, basándose en los arts. 343 y 345 Código civil de Ecuador, traído a la causa a través de informe del Cónsul español en Quito. El Ministerio Fiscal y los promotores recurrieron, alegando la equivalencia de efectos, si bien sin aportar más prueba del Derecho ecuatoriano. La D.G.R.N. estimó el recurso, y lo hizo con base en la aplicación de la nueva regulación ecuatoriana de adopción, el Código de Menores de 1992, que había sustituido al Código civil ecuatoriano. El dato relevante es que esta normativa fue aportada directamente por la D.G.R.N. con base en su propio conocimiento (podría decirse, de oficio), ya que ni Juez Encargado ni Ministerio Fiscal o interesados la aportaron, ni en su resolución consta cómo la D.G.R.N. llegó a conocer el tenor del Derecho ecuatoriano.

Lo mismo podría decirse de la más reciente Res. DGRN de 21 de octubre de 2008, sobre inscripción de adopción, respecto de la inscripción de un menor guatemalteco que había sido adoptado conforme a la legislación de su Estado por un nacional hispano-estadounidense y una nacional española residentes en EE.UU.: en este caso, la D.G.R.N., en la valoración de los efectos de la adopción constituida ante la autoridad extranjera, llega a la conclusión de que "...la adopción guatemalteca sólo produce efectos entre adoptante y adoptado...", si bien no muestra en su resolución cómo ha llegado al conocimiento del Derecho guatemalteco, no empleando tampoco la fórmula al uso.

El Ministerio Fiscal, por su parte, en aquellos casos en los que se opone a lo decidido por el Juez Encargado del Registro, lo hace con base en la descripción que el propio órgano ministerial realiza sobre el Derecho extranjero, si bien sin que conste específicamente cómo ha llegado a su conocimiento ${ }^{34}$. Es lo que se observa en la Res. DGRN de 12 de julio de 1996, sobre inscripción de adopción dominicana; o en la Res. DGRN de 14 de marzo de 2007, sobre inscripción de adopción, en la que el Ministerio Fiscal estima que “...la

\footnotetext{
${ }^{33}$ Res. DGRN de 6 de mayo de 2000, sobre adopción; Res. DGRN de 5 de febrero de 1998, sobre inscripción de adopción nepali; Res. DGRN de 14 de febrero de 1998, sobre adopción nepalí; Res. DGRN de 6 de marzo de 1997, sobre inscripción de adopción china; o Res. DGRN de 16 de septiembre de 1996, sobre adopción mexicana (B.I.M.J., $\mathrm{n}^{\circ}$ 1792, p. 624; R.E.D.I., 1998-I, p. 310, con nota de EsteBAn DE LA Rosa, G.); Res. DGRN de 15 de abril de 2008, sobre inscripción de adopción.

${ }^{34}$ Por ejemplo, Res. DGRN de 12 de julio de 1996, sobre inscripción de adopción dominicana (B.I.M.J., nº 1788-1789, p. 113; R.E.D.I., 1997-II, p. 270, con nota de CALVo B ABío, F.).
} 
legislación hindú contempla que la adopción es plena...", si bien sin pronunciarse respecto a cómo llegó a este conocimiento. Idéntica forma de actuar se refleja en la Res. DGRN de 21 de marzo de 2006, sobre opción a la nacionalidad española y adopción marroquí, en la que el Ministerio Fiscal “....informó que, de acuerdo con la legislación marroquí, la Kafala no establece ningún vínculo de filiación...".

La parte interesada (de ordinario, los adoptantes) no suele aportar el Derecho extranjero, labor que tampoco le viene exigida por la D.G.R.N. ${ }^{35}$, limitándose más bien valorar su tenor cuando recurre la decisión del Juez Encargado del Registro ${ }^{36}$. La razón puede estar tal vez no tanto en una cierta pasividad de la parte, como en las dificultades y en el desconocimiento que tienen los particulares en cuanto a dónde y a quién acudir para obtener los certificados acreditativos de la ley extranjera que se les exigen o son necesarios en el Registro Civil ${ }^{37}$.

Tal es así en la Res. DGRN de 7 de diciembre de 2002, sobre adopción guatemalteca, en la que el Juez Encargado del Registro Civil Central deniega la inscripción de adopción por revocabilidad de las adopciones guatemaltecas (según información de la Embajada de Guatemala en Madrid), que fue recurrida por los promotores alegando éstos que la adopción era irrevocable, y, de nuevo, sin aportar norma guatemalteca que lo demostrase. Lo mismo sucedió en la Res. DGRN de 4 de julio de 2005, sobre inscripción de adopción argentina. En esta línea se halla asimismo la Res. DGRN de 20 de enero de 2009, sobre inscripción de adopción constituida en el extranjero, respecto de la solicitud de inscripción de nacimiento de un hijo adoptado en Guinea Bissau, que es denegada por el Juez Encargado del Registro por infracción del art. 1981 de la Ley Guineana en cuanto establece como requisito para la adopción plena que los adoptantes sean dos personas unidas en matrimonio desde hace más de diez años, no separadas judicialmente y sin descendientes legítimos. Ante ello, el interesado interpone recurso ante la D.G.R.N. solicitando la inscripción de nacimiento de su hijo, alegando que "...la calificación está basada en una legislación no vigente actualmente en Guinea-Bissau como es el Código Civil Portugués de 25 de noviembre de 1966, y que hay efectuadas otras adopciones de Guinea Bissau efectuadas por matrimonios de menos de 10 años, y también hay adopciones monoparentales...". Y todo ello, que es lo que ahora interesa, sin traer prueba del cambio en la ley extranjera vigente, ni

${ }^{35}$ En este sentido, EstebAn DE LA Rosa, G. (coord), Regulación de la adopción internacional..., op. cit., p. 303. Con matices, CALvo BABío, F., Aplicación judicial del Derecho extranjero..., op. cit., p. 71.

${ }^{36}$ Calvo Caravaca, A.L./Carrascosa González, J., Derecho de familia internacional..., op . cit., 2004, p. 316, respecto del papel poco activo que desempeña la parte interesada.

${ }^{37}$ Con carácter general, LóPEZ-BERMEJo MuÑoz, J., "Evolución estadística de la inmigración y repercusión en el Registro Civil”, en Registro Civil..., op. cit., p. 94. 
de norma y/o práctica jurisdiccional de este Estado extranjero que refrendase su alegación. La D.G.R.N. desestima el recurso, entendiendo que la adopción fue constituida con infracción de la ley de Guinea-Bissau, limitándose a justificar su tenor "....conforme al conocimiento oficial adquirido por este Centro Directivo del contenido material del Derecho aplicable en materia de adopciones en Guinea Bissau, obtenido por mediación de la Embajada de España en D...”, y sin llegar a valorar tampoco en su Resolución la existencia o no de una sucesión de leyes en el tiempo (conflicto internacional transitorio).

Solamente en dos de los casos analizados la parte introdujo el Derecho extranjero $^{38}$. En uno, en concreto, la ley venezolana de adopción de 1983, que había sustituido a la ley de 1972, y lo hizo a través de fotocopias, como se ve en Res. DGRN de 11 de marzo de 1997, sobre inscripción de adopción venezolana $^{39}$. Y en otro, el Código de Menores ecuatoriano de 1992 que había derogado tácitamente a los arts. 332 y ss Código de Ecuador, y que fue introducido a partir de una certificación del Tribunal de Menores de G. (Ecuador) debidamente legalizado por el Consulado de España en Ecuador, en el que "... se certifica que las adopciones que se conceden en este país se rigen por el Código de Menores de 1992...", tal como se dice en la Res. DGRN de 9 de septiembre de 2002, sobre inscripción de adopción ecuatoriana.

En el ámbito extrajudicial, el papel de las partes no es tan determinante como en el judicial. Las reglas especiales que, con carácter general, regulan la aplicación de una ley extranjera por autoridades no judiciales conceden, como veremos, un papel importante a las propias autoridades a la hora de su acreditación (por ejemplo: suficiencia del propio conocimiento privado como título para acreditar y aplicar un Derecho extranjero). Incluso en aquellos casos en los que la práctica de la D.G.R.N. viene exigiendo que el Derecho extranjero sea objeto de prueba por las partes interesadas, como sucede en el ámbito del Registro de la Propiedad a la hora de probar la ley extranjera aplicable a la capacidad de obrar y a la forma de un acto a fin de acceder a este Registro (p.e.: Res. DGRN de 27 de abril de 1999; o Res. DGRN de 19 de febrero de 2004), puede eximirse de esta prueba si el Registrador acredita conocimiento suficiente de este Derecho extranjero (art. $36 \mathrm{RH}$ ). Por el contrario, en el ámbito de la aplicación judicial de la ley extranjera, y de acuerdo con lo que es la práctica mayoritaria en el ordenamiento jurídico español, el papel de las partes es determinante, habida cuenta de que se les exige la alegación y prueba de la vigencia, contenido e interpretación del Derecho extranjero para proceder a su aplicación ${ }^{40}$.

${ }^{38}$ Lara Aguado, A., "Adopción internacional...", loc. cit., p. 131, que habla de la posibilidad de la parte interesada de aportar efectivamente la ley extranjera; o CALVO BABÍO, F., Aplicación judicial del Derecho extranjero..., op. cit., p. 71.

${ }^{39}$ Res. DGRN de 11 de marzo de 1997 (B.I.M.J., no 1823, p. 1509).

${ }^{40}$ Sobre esta cuestión, Virgós Soriano, M./Garcimartín AlfÉREZ, F.J., Derecho procesal civil internacional..., op . cit., 2007, pp. 526-530; GARCIMARTín AlFÉREZ, F.J., Sobre la norma de conflicto..., op. cit., passim. 


\section{B. El PAPEl DE LA D.G.R.N. EN LA APORTACión DEL DeREChO EXTRANJERO: DESARROLLO.}

Y se ha empleado la palabra parece a la hora de poner de manifiesto que es el Juez Encargado del Registro, el Ministerio Fiscal o la propia D.G.R.N. quien se encarga de oficio de aportar el Derecho extranjero, en vista de que los términos empleados para decidir esta cuestión, lejos de ser tajantes, resultan vagos e imprecisos ${ }^{41}$. Así, tal como hemos visto, se habla de "...de acuerdo con el conocimiento adquirido de la legislación china...”, o “...en vista de las informaciones obtenidas sobre la legislación mexicana...", y nunca se emplean expresiones más contundentes como "...tal como ha sido acreditado el Derecho extranjero...”, o “...tras prueba plena del Derecho extranjero...”.

Podría entenderse, no obstante y al igual que sucede en sede jurisdiccional, que no existe una obligación por parte de un Juez Encargado del Registro o de una D.G.R.N. que desconozca la normativa extranjera de averiguar por sus propios medios su vigencia y contenido, normalmente, a través de los medios previstos por el legislador español o por la consulta de la práctica extranjera (consulta a Embajada o Cónsul, Notario, y resto de medios), dado que el art. 281.2 Ley de Enjuiciamiento Civil 2000, tal como viene siendo entendido, ubica en la parte interesada la carga de probar la normativa extranjera. El éxito de la parte interesada en el resultado de esta tarea permitiría a la D.G.R.N. tomar en consideración la ley extranjera y proceder, en su caso, a la inscripción de la adopción. Por el contrario y siguiendo con este razonamiento, su pasividad o actividad deficiente en torno a la prueba debería conducir, tal como veremos, a negar la inscripción, habida cuenta de que no se ha conseguido ilustrar suficientemente a la D.G.R.N. en el contenido del Derecho extranjero, $y$, con ello, a situarla en una posición que le permita valorar una posible equivalencia de efectos entre adopción española y extranjera.

Ahora bien, a pesar de lo expuesto, no debería dejar de considerarse la posibilidad de sostener la aportación de la ley extranjera por iniciativa del Juez Encargado del Registro o de la propia D.G.R.N. en estos casos de adopción internacional, tal como parecen estar comportándose estas autoridades en la mayoría de las resoluciones analizadas hasta el momento.

Por una parte, este proceder no está reñido con el tenor del art. 12.6 Código Civil, regulador de la aplicación de una ley extranjera, que entiende la aplicación de oficio de las normas de conflicto del Derecho español referida no sólo a los órganos jurisdiccionales, sino también, como vimos, respecto de las autoridades no judiciales. Ello debería conducir, en consecuencia, a la toma en consideración también de oficio de la ley extranjera reclamada por la normativa española reguladora de la adopción internacional. $\mathrm{O}$, lo que es lo

\footnotetext{
${ }^{41}$ Calvo Caravaca, A.L./Carrascosa González, J., Derecho de familia internacional..., op. cit., 2004, p. 316, hablan de práctica caótica en relación a quién aporta el Derecho extranjero en las resoluciones de la D.G.R.N.
} 
mismo, abandonar en manos de las partes la averiguación del Derecho extranjero, esto es, permitir que el mandato de la norma en su remisión a una ley extranjera pueda no ser ejecutado por una actitud pasiva de las partes (a las partes no les interesa la ley extranjera; o, interesándoles, no consiguen su prueba, o no consiguen convencer al órgano de su tenor), dejaría sin efecto real el mandato original y previo estableciendo su aplicación de oficio (art. 12.6.I Código civil ${ }^{42}$.

Por otra, no debe olvidarse que las legislaciones nacionales en sus diversas expresiones territoriales, así como toda la normativa convencional vigente, regulan la adopción a través de un complejo entramado normativo que se halla sustentado, y esto es lo ahora relevante, en el interés del menor como bien jurídico superior a proteger. Tal es así en el Convenio de La Haya de 29 de mayo de 1993 relativo a la protección de menores y cooperación internacional en materia de adopción internacional y en la Convención de las Naciones Unidas de 20 de diciembre de 1989 sobre los derechos del niño ${ }^{43}$, que inspiran la regulación doméstica, como en la normativa autónoma anterior del art. 9.5 Código Civil y la actual de la Ley 54/2007, de 28 de diciembre, de adopción internacional $^{44}$, como se refleja, por ejemplo, en sus arts. 2 y 4 LAI 2007, que

\footnotetext{
${ }^{42}$ En el ámbito extrajudicial, véase Fernández RozAs, J.C./SÁnchez Lorenzo, S., Derecho internacional..., op . cit., 2009, pp. 167-168; LARA AGUADO, A., "Adopción internacional...", loc. cit., p. 130. Como vemos, se estaría partiendo del hecho de que la aplicación de oficio de una norma de conflicto debería llevar aparejada, en consecuencia, la averiguación también de oficio de la normativa extranjera que reclama. En la práctica jurisdiccional, no obstante, ello no es así: la práctica judicial mayoritaria, como es sabido, habla de la aplicación del Derecho extranjero a instancia de parte, lo que no es consecuente con el párrafo primero del art. 12.6 C.c. por lo ya expuesto. Así se ve, p.e., en la STS de 5 de marzo de 2002, que distingue a aplicación de oficio del art. 9.8 Código Civil, de la aplicación del propio Derecho material extranjero "...que en ningún caso puede ser determinado por el Tribunal...".

${ }^{43}$ Convenio de La Haya de 29 de mayo de 1993 relativo a la protección de menores y cooperación internacional en materia de adopción internacional (Boletín Oficial del Estado, 1 de agosto de 1995); Convención de las Naciones Unidas de 20 de diciembre de 1989 sobre los derechos del niño (Boletín Oficial del Estado, de 31 de diciembre de 1990, $\mathrm{n}^{\circ} 313$ ).

${ }^{44}$ Véase el punto II de la Exposición de Motivos de la Ley 54/2007, de 28 de diciembre, de adopción internacional, cuando dice: "En aplicación de la Constitución y de los instrumentos legales internacionales en vigor para España, esta nueva norma concibe la adopción internacional como una medida de protección de los menores que no pueden encontrar una familia en sus países de origen y establece las garantías necesarias y adecuadas para asegurar que las adopciones internacionales se realicen, ante todo, en interés superior del niño y con respeto a sus derechos. Asimismo, se pretende evitar y prevenir la sustracción, la venta o el tráfico de niños, asegurando al mismo tiempo la no discriminación del menor por razón de nacimiento, nacionalidad, raza, sexo, deficiencia o enfermedad, religión, lengua, cultura, opinión o cualquier otra circunstancia personal, familiar o social. Cabe añadir que la presente Ley debe ser siempre interpretada con arreglo al principio del interés superior de los menores, que prevalecerá sobre cualquier otro interés legítimo que pudiera concurrir en los procesos de adopción internacional”. O el punto III de esta misma Exposición de Motivos de la Ley 54/2007, de 28 de diciembre, de adopción internacional, que habla de "...el objetivo pre-
} 
lo refieren como principio básico, o los arts. 20 o 31 LAI 2007, en sede de constitución de una adopción por autoridad española y de reconocimiento de una resolución extranjera de adopción, respectivamente ${ }^{45}$. O, lo que es lo mismo, en muchas ocasiones el legislador condiciona la labor de las autoridades judiciales y no judiciales españolas que se enfrentan a una adopción internacional a la salvaguarda del interés superior del menor. En el ámbito en el que ahora nos encontramos, que es el del reconocimiento de adopciones constituidas por autoridades extranjeras, el interés del menor podría traducirse en la garantía de la integración del adoptado en la familia de acogida: no parece discutible que uno de los mayores beneficios legales que, en el contexto internacional, existe para un menor necesitado de protección, resulta de su completa integración en una familia adecuada mediante la figura de la adopción, habida cuenta de que es ésta la institución legal que presenta un grado mayor de integración familiar en un núcleo familiar por la conversión del menor adoptado en hijo $^{46}$.

Pues bien, a nuestro juicio, el interés superior del menor podría mediatizar el papel de las autoridades extrajudiciales españolas (y judiciales), en lo que ahora interesa y al igual que sucede en otras sedes, también en el tema de la aplicación de la ley extranjera en el ámbito de las adopciones internacionales. A tal efecto, no es nuevo pensar que la aportación de oficio de la normativa extranjera por parte de la autoridad competente que se halla vinculada por una normativa orientada materialmente va a permitir satisfacer con mayor garantía la finalidad material y la imperatividad reforzada de las normas reguladoras, en este caso, de la adopción internacional: se traerá así a la causa aquella normativa extranjera que permite al Juez Encargado del Registro o a la D.G.R.N. valorar la equivalencia de efectos entre adopción extranjera y española, permitir en su caso la inscripción en el Registro Civil español, y reconocer así al menor adoptado en el extranjero como hijo a efectos del ordenamiento jurídico español, facilitando de este modo la integración plena del menor en la familia de acogida.

tendido por esta Ley de establecimiento de garantías de las adopciones tomando siempre como guía el interés superior de los menores...". Sobre el factor interés del menor y sus límites y contenido, véase BORRÁs RODRíGUEZ, A., "El interés del menor como factor de progreso y unificación", Revista Jurídica de Catalunya, 1994, pp. 915-992; o HerRanz Ballesteros, M., El interés del menor en los Convenios de la Conferencia de La Haya de Derecho Internacional Privado, Valladolid, 2004.

${ }^{45}$ Véase el art. 20 LAI 2007, cuando permite a la autoridad española competente para la constitución de la adopción exigir los consentimientos, audiencias o autorizaciones requeridas por la ley nacional o por la ley de la residencia habitual del adoptante o del adoptando, siempre que repercuta en interés del adoptando; o el art. 31 LAI 2007, que exige tener en cuenta el interés superior del menor respecto de la operatividad de la excepción de orden público a la hora del reconocimiento de una decisión extranjera de adopción.

${ }^{46}$ Así, Calvo BaBío, F., Reconocimiento en España de las adopciones simples realizadas en el extranjero, Madrid, 2003, pp. 31-34. 
En consonancia con lo expuesto y en ausencia de respuesta ad hoc en el contexto extrajudicial, no nos parece adecuado trasladar a este ámbito la práctica mayoritaria que, en sede judicial y en interpretación de los arts. 12.6 Código Civil y 281.2 Ley de Enjuiciamiento Civil 2000, ubica la carga de la alegación y prueba de una ley extranjera, con carácter general, sólo en manos de las partes, con un juez desempeñando una labor fundamentalmente colaboradora. No estamos negando con ello el papel fundamental de la parte: el solicitante que insta la inscripción en el Registro Civil español de una adopción constituida ante una autoridad extranjera es el más interesado en la aportación de aquella normativa que va a permitir al Juez Encargado del Registro o a la D.G.R.N. verificar la equivalencia de efectos entre adopciones e inscribir posteriormente. $\mathrm{Y}$ en eso el sistema lo ampara. Lo que decimos es que el interés superior del menor puede inclinar la balanza a favor de la ubicación de la aportación de la ley extranjera no sólo en manos de las partes, sino también en las del Juez Encargado del Registro o la D.G.R.N. en un contexto en el que queda diluido un eventual principio dispositivo: recuérdese que la Exposición de Motivos de la Ley de Enjuiciamiento Civil 2000 entiende que un eventual principio dispositivo quiebra "...en los casos en que predomina un interés público que exige satisfacción...”. Téngase en cuenta, además, como veremos más adelante, la en ocasiones escasa colaboración de muchas de las Embajadas y Consulados extranjeros acreditados en España, que dificultan la labor de la parte interesada al negarse a expedir certificaciones sobre su legislación incluso a sus propios nacionales ${ }^{47}$.

Visto lo visto, nada impide al Juez Encargado del Registro o a la D.G.R.N. traer la ley extranjera a la causa por propia iniciativa o de oficio, como parece estar sucediendo en la práctica de acuerdo con las resoluciones que hemos analizado, supliendo una eventual pasividad o imposibilidad de la parte. Del mismo modo, nada impide al órgano registral que no conoce el Derecho extranjero completar la falta de actividad probatoria de quien solicita la inscripción a través de los medios de los que dispone ${ }^{48}$. Labor ésta que, con menos dudas, podría entenderse como una obligación cuando, habiendo presentado la parte elementos de prueba suficientes del contenido del Derecho extranjero, el órgano registral (o la D.G.R.N., en nuestro caso) estime que no se encuentra suficientemente ilustrado (no conoce el Derecho extranjero, o, conociéndolo, su percepción difiere de lo aportado por la parte): en este caso, debe ser exigida, antes de actuar en consecuencia (como veremos, rechazando

${ }^{47}$ Sobre ello, Alberdi Vecino, F., "Registro Civil y elemento extranjero...", loc. cit., p. 56; LÓPEZ-BERMEJO MUÑOZ, J., "Evolución estadística de la inmigración y repercusión en el Registro Civil...", loc. cit., p. 94.

${ }^{48}$ Fernández Rozas, J.C., "Comentario al art. 12.6 C.c.”, en Comentarios..., loc. cit., p. 1077, en relación con el Registrador de la Propiedad. 
la inscripción), justificación suficiente de este proceder en orden a desautorizar los elementos probatorios ya presentados ${ }^{49}$.

Con todo ello se garantiza que una eventual no inscripción de la adopción extranjera y, con ello, la no integración plena del menor en la familia de acogida, va a derivar, entre otras razones, de la verificación de una efectiva ausencia de equivalencia de efectos con las adopciones españolas; y no de la ausencia de prueba de la normativa extranjera que permite verificar la existencia o ausencia de esta equivalencia de efectos. Proceder de este modo se ajusta mejor, a nuestro juicio, a las exigencias de la salvaguarda del interés del menor.

En fin, en este orden de asuntos, téngase en cuenta también el papel que juega a la hora de su aplicación el conocimiento privado que del Derecho extranjero tienen las autoridades no judiciales: frente a los órganos jurisdiccionales, cuyo conocimiento no puede suplir la ausencia de prueba del Derecho extranjero en el proceso ${ }^{50}$, el legislador español viene admitiendo a favor de

${ }^{49}$ Arenas García, R., Registro mercantil...op . cit., p. 424, en el ámbito del Registro Mercantil. Recuérdense, en el ámbito jurisdiccional, las repercusiones de la STC 10/2000, de 17 de enero, cuando transforma la facultad reconocida al juzgador en el art. 281.2 Ley de Enjuiciamiento Civil 2000 en un deber con trascendencia constitucional (art. 24.2 Constitución Española): existencia de un derecho de la parte que introduce el Derecho extranjero en el proceso y agota sin éxito los medios de prueba que dispone para su averiguación (conducta diligente), a una activa colaboración judicial en la realización de esta tarea, a través de los medios que el ordenamiento le concede precisamente con este propósito (obtención de prueba plena del Derecho aportado: convencimiento razonable). Sobre ello, CARBALlo PIÑEIRO, L., "El carácter imperativo de la norma de conflicto...", loc. cit., pp. 485-504; MASEDA RodRÍGUEZ, J., "La aplicación judicial del Derecho extranjero: el nuevo régimen de la LEC y la reciente jurisprudencia del Tribunal Constitucional", Actualidad Civil, núm. 12, 2002, pp. 413-446.

${ }^{50}$ FernÁndez Rozas, J.C., "Comentario al art. 12.6 C.c.”, en Comentarios..., loc. cit., par. IX.3, entiende que, en relación a la utilización de su conocimiento privado, el legislador español ha concedido mayor confianza a ciertas autoridades no judiciales (notarios, p.e.) que a los jueces. Es cierto que existe jurisprudencia que, en el ámbito judicial, permite la aplicación del Derecho extranjero a partir del conocimiento que de su tenor tenga el juzgador. Así se ve en la STS de 10 de junio de 2005, que permite al juez aplicar de oficio el Derecho extranjero si lo conoce, como en la Sent. Aud. Prov. Valencia de 3 de abril de 1982 (R.G.D., 1982, pp. 1137-1139), cuando entiende que “...la norma extranjera debe ser objeto de prueba sólo en cuanto sea desconocida por el juzgador, pues, respecto de ella, el principio de aportación de parte no rige como para la prueba de los hechos; esto es, la norma extranjera será objeto de prueba en tanto el Tribunal la desconozca, pero éste puede utilizar sus conocimientos sobre ese Derecho...; lo contrario conduciría al absurdo de que un Tribunal, conociendo el Derecho extranjero, no lo pudiera aplicar...". No obstante, no parece ser intención de la ley permitir al juez suplir la prueba del Derecho extranjero a través de su propio conocimiento: de acuerdo con la jurisprudencia mayoritaria, el art. 281.2 Ley de Enjuiciamiento Civil 2000 ubica en las partes la prueba de la ley extranjera, independientemente de que el juzgador lo conozca. La exigencia de un mínimo principio de prueba en el procedimiento se ajusta mejor a los principios constitucionales, al actuar como garantía constitucional y evitar decisiones arbitrarias. Sobre esta cuestión, Fernández RozAS, J.C./SÁnchEz LoREnZO, S., Derecho internacional..., op. cit., 2009, p. 159. 
las autoridades no judiciales la posibilidad de aplicar la ley extranjera a partir de su propio conocimiento ${ }^{51}$. Así sucede, por ejemplo, con el Juez Encargado del Registro Civil: su conocimiento de la ley extranjera puede resultar suficiente para determinar la adecuación de un hecho o de un documento al Derecho extranjero que se trate (art. 91 Reglamento del Registro Civil), y, en su defecto, ahora sí, puede recurrir a un Notario español, o a un Cónsul español o extranjero ${ }^{52}$. Lo mismo sucede con el Notario que se enfrenta a la aplicación de una ley extranjera cuando otorga escritura pública que afecta a personas de distinta nacionalidad, cuando se califican actos celebrados en el extranjero, casos en los que se plantea la necesidad de aplicación de la ley nacional reguladora de la capacidad (art. 9.1 Código Civil) o cuando deben tenerse en cuenta leyes extranjeras que rigen la validez de un acto o contrato, un tema de sucesiones o la valoración del régimen económico matrimonial de una pareja: de nuevo el legislador admite la posibilidad de la aplicación de la ley extranjera a partir del conocimiento privado que el Notario ha adquirido de esta norma extranjera (art. 168 Reglamento Notarial) ${ }^{53}$. Lo mismo puede decirse en el ámbito del Registro de la Propiedad, donde la autoridad puede hacer valer su propio conocimiento privado a la hora de aplicar la ley extranjera correspondiente a la capacidad de obrar y a la forma y condiciones de la validez de un acto cara al reconocimiento de la fuerza registral de documentos otorgados en el extranjero (art. 36 Reglamento Hipotecario) ${ }^{54}$.

Otra cosa es que sea más o menos aconsejable que la autoridad no judicial complete su conocimiento privado de la ley extranjera con el correspondiente informe o documento emitido por cualquiera de las autoridades permitidas por el legislador español en cada caso (Notario, Cónsul español, Cónsul extranjero, etc...), a fin de que no caiga sobre la autoridad no judicial la responsabilidad que se pudiera derivar de una errónea apreciación del contenido de este Derecho extranjero ${ }^{55}$.

${ }^{51}$ Véase Res. DGRN de 5 de febrero de 2005. También, Fernández Rozas, J.C., "Comentario al art. 12.6 C.c.”, en Comentarios..., loc. cit., pp. 1050-1051; o FERNÁNDEZ ROZAS, J.C./SÁnChez LoREnZo, S., Derecho internacional..., op. cit., 2009, p. 167.

${ }^{52}$ Véase Fernández Rozas, J.C., "Comentario al art. 12.6 C.c.”, en Comentarios..., loc. cit., par. IX.2.

${ }^{53}$ En sus decisiones, el Notario debe hacer constar la circunstancia de aplicación del Derecho extranjero con base en su conocimiento privado, a riesgo de que su decisión pueda ser revocada por la D.G.R.N. (véase Res. DGRN de 1 de marzo de 2005; o Res. DGRN de 5 de febrero de 2005). En el Registro Mercantil, el Registrador, que también puede hacer uso de su conocimiento privado, debe hacerlo constar; sobre ello, ARENAS GARCíA, R., Registro mercantil..., op. cit., p. 422.

${ }^{54}$ Véase también ARENAS García, R., Registro mercantil..., op. cit., p. 422, en relación con admisión del conocimiento privado de la ley extranjera por parte del Registrador en el Registro Mercantil.

${ }^{55}$ Sobre ello, en relación con el Registrador en el Registro Mercantil, ARENAS GARCíA, R., Registro mercantil..., op . cit., pp. 422-423. También, SÁnCHEZ LoRENZO, S., "Algunos problemas del régimen jurídico de los actos inscribibles...", loc. cit., p. 2001. 
Por ello no debería extrañar el papel que el Juez Encargado del Registro o la propia D.G.R.N. juega a la hora de aportar el Derecho extranjero en materia de adopción internacional. Más todavía si tenemos en cuenta el amplio bagaje existente sobre toma en consideración del Derecho extranjero que obra en su poder, lo que permite un amplio conocimiento del mismo. Dado que muchas de las adopciones provienen de los mismos países, la D.G.R.N. opera, sin duda, con dossiers muy fiables relativos a la ley extranjera propios de estos Estados. Repárese, en este sentido, en las Fichas de información sobre los países de origen que aparecen en la página web del Ministerio de Sanidad y Política Social, o en las Consejerías o Consellerías de las diferentes Comunidades Autónomas (por ejemplo: Consellería de Traballo e Benestar de la Xunta de Galicia), lo que, unido a la especialización de la D.G.R.N., en este caso, relativa a adopción internacional, facilita sin duda el acceso a un conocimiento propio y más preciso de la normativa extranjera ${ }^{56}$.

\section{Medios de aportación del Derecho extranjero: flexibilidad}

Una vez visto quién soporta la carga de la aportación de la ley extranjera, respecto del cómo, la práctica analizada, tanto la posterior a 2007 de entrada en vigor de la nueva Ley como la anterior, viene mostrando una flexibilidad importante en el desarrollo de esta fase, así como la utilización y asunción de múltiples medios ${ }^{57}$. La valoración, en principio, positiva de este dato, contrasta, no obstante, con la crítica a la actuación de la D.G.R.N. cuando viene entendiendo como suficientes una serie de medios para llegar al conocimiento del Derecho extranjero, a nuestro juicio, poco fiables o imprecisos, más todavía si se toma como referencia cómo discurre esta fase en sede judicial.

En la práctica judicial, como es sabido, son más rígidos los medios a partir de los cuales se trata de aportar la ley extranjera: con carácter general, prueba pericial (dos jurisconsultos del país extranjero); más prueba documental a través de documentos públicos o intervenidos por fedatario público (autoridad ministerial correspondiente; diplomáticos o cónsules españoles en el extranjero, o extranjeros en España). Con todo, en este ámbito, se observa una tendencia saludable a la flexibilización: se sigue requiriendo una prueba documental (p.e.: certificación emitida por las autoridades consula-

${ }^{56}$ LARA AguAdo, A., “Adopción internacional...”, loc. cit., p. 132, que alude a las Fichas de Legislación de adopción internacional por países que se encontraban en la página web del, en aquellos momentos, Ministerio de Trabajo y Asuntos Sociales.

${ }^{57}$ Señalando esta flexibilidad en el empleo de distintos medios de averiguación de la ley extranjera en sede de resoluciones de la D.G.R.N. en materia de adopción, LARA AGUADO, A., "Adopción internacional...", loc. cit., p. 131; CAlvo CARAVACA, A.L./J. CARRASCOSA GONZÁlEZ, J., Derecho de familia internacional ..., op . cit., 2004, p. 316; MASEDA RodRÍGUEZ, J., "La toma en consideración del Derecho extranjero por la D.G.R.N. ...", loc. cit., pp. 351-360. 
$\operatorname{res}^{58}$ ), que a veces opera como prueba única de acreditación de la ley extranjera $^{59}$, esto es, suficiente para llegar al conocimiento de su alcance, contenido e interpretación, esto es, sin tener que recurrir a prueba pericial complementaria, dada la no necesidad de una interpretación especial ${ }^{60}$. En la práctica registral, en cambio, la idea general es la flexibilización. Con carácter general, la D.G.R.N. admite como medios de prueba documental también los documentos privados o generales, las colecciones legislativas o las obras doctrinales, que no son admitidos en sede judicial; y, además, la D.G.R.N. viene entendiendo la no necesidad de una prueba pericial, a pesar de que la prueba documental sólo puede aportar el texto literal de la ley extranjera y, eventualmente, su vigencia, pero no su alcance e interpretación ${ }^{61}$. De ahí la posibilidad que tiene el Encargado del Registro Civil, por ejemplo, de acudir, además de a su conocimiento privado, en su defecto y alternativamente, a testimonio del Cónsul extranjero en España, del Cónsul de España en ese Estado extranjero, o testimonio de un notario español, para "...comprobar la adecuación de un hecho o documento al Derecho extranjero..." (art. 15 Ley del Registro Civil; art. 91 Reglamento del Registro Civil) ${ }^{62}$; o de acudir al título público correspondiente, a una certificación oficial del Re-

${ }^{58}$ Véase, por ejemplo, la Sent. Aud. Prov. de Barcelona de 28 de septiembre de 2004, respecto de la certificación del Cónsul general de Suiza, adjuntando fotocopias en las que certifica la reproducción fiel y exacta del original publicado en el Recueil systématique du droit federal (FD. III), con su correspondiente traducción.

${ }^{59}$ Véase, por el contrario, la STS de 23 de octubre de 1992 (Ref. Aranzadi, ${ }^{\circ} 8280$, con nota de MASEDA RodríGuez, J., R.E.D.I., 1993-II, pp. 500-509), respecto de la no-suficiencia de la prueba pericial única, requiriendo documental; tampoco, mero informe emitido por letrado extranjero, en el caso, irlandés, en la Sent. Aud. Prov. de Granada de 19 de julio de 2003, que no constituyó prueba suficiente.

${ }^{60}$ Así, Fernández Rozas, J.C./SÁnchez Lorenzo, S., Derecho internacional..., op . cit., 2009, p. 164. Así se entiende, p.e., en la Sent. Aud.Prov. de Granada de 19 de julio de 2004, en la que, aportado en autos la Ley Irlandesa de Sucesiones de 1965, actualmente vigente y debidamente traducida, remitida por el Goverment Publications-Sur Allianz. House, el juzgador se considera suficientemente ilustrado sobre los límites de la facultad de testar y disponer, sobre las legítimas (art. 76 Act 1965) y sobre la interpretación del art. 117 Act 1965, que entiende, en relación a los hijos, como un "...derecho alimenticio a cargo de la herencia...", "...interpretación que haya de darse desde nuestra óptica resulta meridiana y no exige mayor probanza..." (FD III); o en la Sent. Aud. Prov. de Barcelona de 28 de septiembre de 2004 , en la que se afirma que "...la referencia a la falta de jurisprudencia de los Tribunales suizos debe rechazarse..., pues entendemos que la interpretación del art. 91.1 Ley suiza... no genera dudas interpretativas" (FD V).

${ }^{61}$ Fernández Rozas, J.C./SÁnCHEZ LoREnZo, S., Derecho internacional ..., op. cit., 2009, p. 163.

${ }^{62}$ Véase Fernández Rozas, J.C., "Comentario al art. 12.6 C.c.”, en Comentarios..., loc. cit., par. IX.2, que critica esta disposición, entendiendo que debería otorgarse un carácter diferente a estas alternativas, esto es, si es más sencillo acreditar o probar un Derecho extranjero por Cónsul extranjero en España que por Notario español, partiendo de que, como regla general, el conocimiento del Derecho extranjero siempre será más exacto y riguroso por el funcionario extranjero. 
gistro extranjero regular y auténtico, o la declaración oficial extranjera, a la hora de aplicar un Derecho extranjero en relación a hechos acaecidos en el extranjero que afecten al estado civil de españoles y a hechos acaecidos en España que afecten al estado civil y que se rijan por una ley extranjera (art. 38.3 Ley del Registro Civil; art. 152 Reglamento del Registro Civil). Y de ahí también que sea habitual recurrir a comunicaciones directas por correo, fax o por vía telemática con organismos públicos, registros y en el ámbito consular (por ejemplo: Consulta a la DGRN de 2 de diciembre de 2004 y de 10 de febrero de 2005, sobre adopción de menor vietnamita); o que se empleen habitualmente comisiones rogatorias (Res. DGRN de 13 de julio de 1956), comunicaciones telefónicas (Res. DGRN de 13 de octubre de 1976), dictámenes del Consejo de Estado (Orden de 1 de febrero de 1979) o de la Cámara de Comercio (Res. DGRN de 14 de agosto de 1971), o resoluciones anteriores que contienen el Derecho extranjero que resulta aplicable ${ }^{63}$.

El primero de los medios habituales referidos en la práctica analizada de la D.G.R.N. en materia de adopción internacional hace referencia a las fotocopias $^{64}$. A estos efectos, cuando se habla de fotocopias, se alude a las meras fotocopias o fotocopias simples, $\mathrm{y}$, aunque en muchas ocasiones no se especifica, podrían ser entendidas como reproducciones de Códigos de legislación, compilaciones, manuales o publicaciones especializadas en las que se reproduce la normativa extranjera sobre adopción. Con todo, si bien esto es así, lo cierto es que cuando se especifica el origen de la fotocopia, éste suele coincidir con Códigos civiles o leyes especiales de adopción, tal como sucede, por ejemplo, con la Res. DGRN de 12 de julio de 1996, sobre inscripción de adopción dominicana, en la que se adjuntan fotocopias del Código civil dominicano sobre adopción.

Junto con fotocopias simples, muchas de las resoluciones analizadas introducen el concepto de fotocopias compulsadas. Ahora bien, a pesar del empleo de este término, su significado resulta de difícil comprensión; o, lo que es lo mismo, el uso de este término por parte de la D.G.R.N. no aclara las dudas respecto de qué debe entenderse exactamente por una fotocopia compulsada:

\footnotetext{
${ }^{63}$ Poniendo de manifiesto esta flexibilidad en el empleo de distintos medios de averiguación de la ley extranjera, más en general, en el ámbito extrajudicial de aplicación del Derecho extranjero, AlBERDi VeCino, F., "Registro Civil y elemento extranjero. Problemática en cuanto a la ley aplicable", en Registro Civil: incidencia del fenómeno de la inmigración, Cuadernos de Derecho Civil, 2004, pp. 39-81, espec. p. 54; FERnÁNDEZ ROZAS, J.C./SÁNCHEZ LORENZo, S., Derecho internacional..., op. cit., 2009, p. 170; SÁNCHEZ LoRENZO, S., “Algunos problemas del régimen jurídico de los actos inscribibles...", loc. cit., p. 2001. En particular, en materia de adopción internacional, en relación al recurso a a comunicaciones directas por correo, fax o por vía telemática con organismos públicos, registros y en el ámbito consular, LARA AGUADO, A., “Adopción internacional...”, loc. cit., p. 131.

${ }^{64}$ Esteban De la Rosa, G. (coord), Regulación de la adopción internacional..., op. cit., p. 303; Calvo Caravaca, A.L./Carrascosa González, J., Derecho de familia internacional..., op. cit., 2004, p. 316.
} 
se desconoce cuál es el objeto de la compulsa, que bien pudiera ser de un código de leyes, de un manual o de una monografía especializada. Además, y a la escasa claridad de la descripción de este medio de prueba, se le añaden más datos que contribuyen a generar una mayor confusión. Tal es así cuando, además, existen casos en los que la mera fotocopia prevalece frente a la fotocopia compulsada, con lo que ya no es sostenible un supuesto carácter privilegiado de la fotocopia compulsada frente a la simple ${ }^{65}$. Así se ve en la Res. DGRN de 11 de marzo de 1997, sobre inscripción de adopción venezolana ${ }^{66}$, donde el Juez Encargado del Registro ordenó que se unieran a las actuaciones fotocopia compulsada de la vigente ley venezolana de 20 de junio de 1972, denegando la inscripción por la revocabilidad de la adopción venezolana. El interesado unió al recurso fotocopia de la ley venezolana vigente de 18 de agosto de 1983, afirmando la irrevocabilidad de la adopción venezolana. La D.G.R.N., por su parte, admitió las fotocopias en su variante de no-compulsadas, estimó el recurso y revocó el acuerdo apelado (favor adoptionis).

Además de las fotocopias en cualquiera de estas variantes, se emplean como medio de aportación del Derecho extranjero los informes de consulados y Embajadas, tanto de Cónsules extranjeros en España como de Cónsules españoles en el extranjero ${ }^{67}$. Como muestra, la Res. DGRN de 4 de octubre de 1996, sobre adopción brasileña, en la que se aportó informe del Cónsul español en Río de Janeiro, relativo al art. 40 de la ley brasileña de adopción ${ }^{68}$; la Res. DGRN de 5 de febrero de 1998, sobre inscripción de adopción nepalí, en la cual se aportó informe del Cónsul de Nepal en Barcelona respecto de la ley nepalí de adopción ${ }^{69}$; la Res. DGRN de 19 de noviembre de 2005, sobre inscripción de adopción, en la que la Embajada de España en Haití aportó copia de la legislación haitiana sobre adopción e información sobre sus efectos; la Res. DGRN de 20 de enero de 2009, sobre inscripción de adopción constituida en el extranjero, en la que la Embajada de España en Guinea-Bissau aporta la normativa reguladora de las adopciones internacionales propia de este Estado; o la Res. DGRN de 26 de febrero de 2010, de adopción internacional, ya al amparo de la nueva Ley de adopción, cuando habla de “...lo dispuesto al respecto por la Ley de la República de Kazajstán sobre el Matrimonio y la Familia de 17 de diciembre de 1998 - según el conocimiento oficial adquirido de la misma por este Centro Directivo a través de la traducción al español de su original

${ }^{65}$ Esteban de la Rosa, G. (coord), Regulación de la adopción internacional..., op . cit., p. 303, que habla de la escasa sofisticación de las fotocopias como medio de prueba.

${ }^{66}$ Res. DGRN de 11 de marzo de 1997, cit..

${ }^{67}$ Con carácter general, AlBerdi VeCino, F., "Registro Civil y elemento extranjero...", loc. cit., p. 55, señala el predominio de la búsqueda de información sobre la ley extranjera a través de Cónsules en el ámbito extrajudicial.

${ }^{68}$ Res. DGRN de 4 de octubre de 1996, sobre adopción brasileña (B.I.M.J., nº 1794, p. 888).

${ }^{69}$ Res. DGRN de 5 de febrero de 1998, sobre inscripción de adopción nepalí. 
ruso que, procedente de la Embajada de España en Kazajastán, se ha recibido a través de comunicación de la Dirección General de Asuntos y Asistencia Consulares...". Repárese, asimismo, en la Res. DGRN de 20 de enero de 2009, sobre inscripción de adopción (surcoreana), en la que, entre otros medios, la D.G.R.N. llega al "...conocimiento oficial de la legislación surcoreana en materia de adopciones internacionales de niños de dicha nacionalidad...", a partir de "...la contestación remitida por el Ministerio de Sanidad y Bienestar de Corea del Sur a la Embajada de España en Seúl...”.

Asimismo, se recurre a resoluciones anteriores de la D.G.R.N. en las que se tomó en consideración el mismo Derecho extranjero ${ }^{70}$. En este sentido, la Res. DGRN de 6 de mayo de 2000, sobre adopción vietnamita, a la hora de valorar el art. 39 de la ley vietnamita a los efectos de ponderar la adopción vietnamita y española, afirma: “...como ya lo indicó la Resolución de 1 de junio del pasado año, el art. 39 de la ley vietnamita..." ${ }^{\prime 1}$. O la Res. DGRN de 1 de febrero de 2007, sobre inscripción de adopción etíope, donde, “...para la compleja exégesis comparativa entre el Derecho extranjero (en este caso, etíope) y el Derecho español...", se ayuda de su propia Res. DGRN de 6 de abril de 2006, sobre inscripción de adopción etiope, tal como se deduce de la frase empleada en su resolución del tenor de "...partiendo de la prueba del Derecho extranjero disponible en ese momento...". Lo curioso es que en esta Resolución de 2006 en la que se apoya la autoridad para informarse sobre el Derecho etíope no se indica realmente cómo se aporta su tenor (de hecho, a pesar de todo, son numerosas las resoluciones de la D.G.R.N. en las que se remite a esta Res. DGRN de 6 de abril de 2006, como puede verse en la Res. DGRN de 1 de diciembre de 2008, sobre inscripción de adopción, o Res. DGRN de 6 de mayo de 2009, sobre inscripción de adopción). En este orden de asuntos, llama la atención la Res. DGRN de 23 de noviembre de 2006, sobre inscripción de adopción, en la que "...se solicitó (desde el Registro Civil Central) al Consulado General de España en Etiopía informe sobre los efectos que tiene la adopción en Etiopía..., remitiendo la Embajada de España en Addis Abeba copia de la Res. DGRN de 6 de abril de 2006...", esto es, la misma resolución referida antes y que procede asimismo de un operador jurídico español (y no extranjero), y ello, aunque se trataba de aportar el tenor de una ley extranjera.

Por otra parte, y como medio de aportación del Derecho extranjero, también se apela, con carácter general, a lo que podemos llamar informes varios.

\footnotetext{
${ }^{70}$ Respecto del empleo habitual en la práctica registral de resoluciones anteriores, véase en esta sede de inscripción de adopciones, CALVO CARAVACA, A.L./CARRASCOSA GonZÁLEZ, J., Derecho de familia internacional..., op . cit., 2004, p. 316; MASEDA RodRíGUEZ, J., "La toma en consideración del Derecho extranjero por la D.G.R.N. ...", loc. cit., pp. 351-360. Más en general, Fernández RozAs, J.C./SÁnCHEZ LoREnzo, S., Derecho internacional..., op. cit., 2009, p. 170.

${ }^{71}$ Res. DGRN de 6 de mayo de 2000, sobre adopción. En general, respecto a la vinculación entre autoridades no judiciales sobre la apreciación de la ley extranjera, FERNÁNDEZ RozAS, J.C., "La aplicación del Derecho extranjero por los notarios", loc. cit., p. 207.
} 
Sobre este medio, llaman la atención algunos casos concretos. Repárese así en aquel supuesto en el que se atiende a un informe de unas jornadas que, sin especificar claramente a qué se refiere, parece ser el resumen de unas jornadas divulgativas sobre adopción internacional. Se trata de la Res. DGRN de 30 de marzo de 1999, sobre adopción vietnamita, donde el Encargado de Asuntos Consulares del Registro civil de España en Hanoi denegó la inscripción de una adopción vietnamita por carecer ésta de los efectos que la legislación española atribuye a las adopciones, procediendo de este modo en atención a las instrucciones recibidas del Ministerio de Asuntos Exteriores núm. 269 de 30 de junio de 1998 y núm. 404 de 11 de octubre de 1996, que califican las adopciones vietnamitas como simples. El interesado recurre ante la D.G.R.N. alegando, entre otras razones, que la citada instrucción 269 sólo hace referencia a unas jornadas sobre la adopción celebradas en Madrid. La D.G.R.N. estima el recurso y considera que la adopción vietnamita es plena, si bien no se apoya en este dato concreto del "...informe de las jornadas...", sino que lo hace en el conocimiento que tiene del Derecho vietnamita. Por ello, rechaza los argumentos del Cónsul encargado del Registro civil de España en Hanoi en lo que éste entiende que la adopción es menos plena basándose en el hecho de que el adoptante tenga que informar periódicamente al Comité Popular que la decidió en Vietnam o que el art. 30 Ley vietnamita de la nacionalidad establezca que la adoptada conserva la nacionalidad vietnamita. La D.G.R.N. considera estas cuestiones como irrelevantes, midiendo la compatibilidad de efectos conforme a otros parámetros. Repárese, también, en la Res. DGRN de 21 de febrero de 2007, sobre inscripción de adopción etíope, en la cual se aporta el Derecho etíope a partir de un informe de la DGRN dirigido a la Asociación de Familias de Niños y Niñas de Etiopía (AFNE), en el que se pronunciaba a favor de su calificación como adopciones plenas, y en contra de la Juez Encargada del Registro Civil, que, apoyándose en resoluciones anteriores de la D.G.R.N., entendía que la adopción etíope era simple (y no inscribió).

En fin, respecto de los medios de prueba, podría hablarse finalmente de un apartado genérico, un supuesto cajón de sastre en la que podrían agrupar aquellos casos en los que se aporta el Derecho extranjero a través de medios menos habituales. Sirva como muestra la Res. DGRN de 9 de septiembre de 2002, sobre inscripción de adopción ecuatoriana, en la que se aporta el Código de Menores ecuatoriano de 1992 a partir de una “...certificación..." del Tribunal de Menores de G. (Ecuador) debidamente legalizado por el Consulado de España en Ecuador. También, la Res. DGRN de 12 de junio de 2002, sobre inscripción de adopción internacional, en la que, si bien no era necesario, el interesado aporta "... escrito en el que se traslada consulta al Instituto Catalán de Acogimiento y Adopción de la Consellería de Justicia de la Generalitat de Cataluña, que manifestaba que, según el Código de Familia de la República de Ucrania (constatado por los Tribunales de Ucrania competentes en adopción) no es necesario certificado de idoneidad para la adopción de un hijo del cónyuge...". O la Res. DGRN de 3 de abril de 2002, sobre inscrip- 
ción de adopción, respecto de una solicitud de inscripción de una adopción constituida en Guatemala por un matrimonio de español más holandesa a favor de una menor guatemalteca, en la que el adoptante aporta prueba de la plenitud de la adopción guatemalteca, a diferencia de lo que pensaba el Juez Encargado del Registro Civil Central, y lo hace a través de un "... auto de adopción dictado por Tribunal holandés...": la D.G.R.N. consideró la no-equivalencia según la ley de Guatemala, de la que no se dice cómo se aporta (probablemente, con base en el propio conocimiento de la D.G.R.N.). También, en fin, en Res. DGRN de 20 de enero de 2009, sobre inscripción de adopción (surcoreana), en la que se trata de aportar el contenido del Derecho de Corea del Sur, entre otros medios, a partir de un genérico "... documentos obrantes en el expediente expedidos por autoridades coreanas...".

\section{Valoración de la ley extranjera por parte de la D.G.R.N}

\section{A. ALCANCE E INTERPRETACIÓN DE LA LEY EXTRANJERA}

En fin, una vez traído al caso el Derecho extranjero, la siguiente fase pasa por la exposición de su valoración o qué consecuencias podrían extraerse de su aportación.

En la mayoría de los casos, se produce una cierta discrepancia, no sobre el contenido del Derecho extranjero, sino sobre su alcance o interpretación.

En lo que ahora interesa respecto de las resoluciones consultadas, el debate jurídico se produce sobre los efectos de la adopción constituida ante autoridad extranjera, a la hora de decidir su calificación como plena o simple desde la óptica del ordenamiento jurídico español, si bien no se discute el tenor del Derecho extranjero. En este sentido, de las resoluciones analizadas, extraemos un dato: la interpretación de la normativa extranjera traída a la causa, es decir, su alcance, suele ser realizada directamente por la D.G.R.N. $\mathrm{O}$, lo que es lo mismo, del Derecho extranjero se aporta su tenor material, pero no su interpretación tal como la realizan los Tribunales y autoridades del Estado extranjero: ésta suele realizarse directamente por la D.G.R.N. de la lectura de preceptos concretos del Derecho extranjero.

Así se observa en la Res. DGRN de 26 de febrero de 2010, de adopción internacional, donde es la propia D.G.R.N. quien valora directamente el alcance de una serie de preceptos propios de la Ley de la República de Kazajstán sobre el Matrimonio y la Familia de 17 de diciembre de 1998 relativos a la revocabilidad de la adopción extranjera a la hora de denegar la inscripción por ausencia de equivalencia de efectos exigida en el art. 26 LAI 2007. O en la Res. DGRN de 1 de febrero de 2007, sobre inscripción de adopción etíope, donde, una vez aportado, entre otros, el art. 183.3 Código de Familia etíope, su alcance resulta determinado directamente por la D.G.R.N. al apoyar su actuación "....según interpretación más plausible del transcrito precepto...”; o, aportado el art. 195 y 806 Código de Familia etíope, la D.G.R.N. llega al convencimiento de su tenor sin necesidad de acudir a doctrina y/o jurisprudencia 
extranjera, cuando actúa de acuerdo a "...lo que pone de manifiesto este último precepto...", "...sea cual fuere el criterio jurídico interno utilizado por el ordenamiento jurídico etíope para la superación de tal contradicción...". Mismo comportamiento ofrece la D.G.R.N. en la Res. DGRN de 1 de diciembre de 2008, sobre inscripción de adopción, donde procede directamente “...a la compleja exégesis comparativa entre el Derecho extranjero (en este caso, etíope) y el español...”, entendiendo que “...en la adopción etíope el niño adoptado será considerado, a todos los efectos, hijo del adoptante (art. 181. Effects: "an adopted child shall, for all purposes, be deemed to be the child of the adopter")...". En este caso, la D.G.R.N. llega a determinar el ámbito de aplicación de la norma etíope, como sucede cuando, sin citar jurisprudencia extranjera o prueba documental alguna, estima que “...de acuerdo con la Ethiopian Nationality Proclamation (núm. 378/2003), a los efectos de la atribución o reconocimiento de la nacionalidad etíope, el término niño incluye a los niños adoptados (cfr. art. 2 núm. 3)..." (lo mismo hace en Res. DGRN de 16 de febrero de 2009, sobre inscripción de adopción); o llega a identificar que "....en la legislación etíope encontramos en este punto (art. 180 n. ${ }^{\circ} 1$ del Código civil etíope, cuando categóricamente dispone que la adopción es irrevocable) una clara antinomia...", que se encarga directamente tanto de aclarar "...sea cual fuere el criterio jurídico interno utilizado por el ordenamiento jurídico etíope para la superación de tal contradicción...", como de establecer las pautas de su interpretación, al entender que "...lo que pone de manifiesto este último precepto (art. 806 Código civil etíope, cuando dice que la "...adoption may not be revoked for any reason...") es que frente a un principio general tan categórico cualquier excepción habrá de ser interpretada cautelosa y restrictivamente y siempre en beneficio e interés del menor...".

En este orden de asuntos, significativa es también la Res.DGRN de 15 de abril de 2008, sobre inscripción de adopción, en la que la D.G.R.N., además de seguir su línea de interpretación directa del Derecho extranjero, lo que se refleja en sus palabras de "...cabe deducir de la redacción de dicho artículo..." (art. 138 Ley núm. 136-03 Código del Menor dominicano), llega a interpretar su tenor atendiendo no a los parámetros interpretativos de la ley extranjera, sino de acuerdo con los parámetros de la lex fori: “...sin embargo, por identidad de razón cabrá aplicar a la interpretación de las normas antes referidas del Derecho dominicano sobre el certificado de idoneidad los mismos criterios empleados para la hermenéutica de la correlativa norma española contenida en el citado artículo 9 núm. 5-IV, basado siempre en la preservación del superior interés del menor...."72.

${ }^{72}$ No extraña esta forma de actuar de la D.G.R.N. respecto de la interpretación de la ley extranjera. Téngase en cuenta que, en sede judicial, la forma de proceder es semejante. Véase, por ejemplo, Sent. Aud. Prov. de Granada de 19 de julio de 2004, o STS de 23 de octubre de 1992 (Ref. Aranzadi, n ${ }^{\circ} 8280$ ); ampliamente, MASEDA RodRÍGUEZ, J., "La interpretación judicial del Derecho extranjero", Rev. Der. Privado, 1997, pp. 793-822. 


\section{B. CONTENIDO DE LA LEY EXTRANJERA}

En otras ocasiones, menos numerosas, la discrepancia se produce sobre el propio contenido del Derecho extranjero, tal como sucede en la Res. DGRN de 11 de marzo de 1997, sobre inscripción de adopción venezolana ${ }^{73}$, en la que el Juez Encargado resuelve con base en la ley venezolana de 20 de junio de 1972, denegando la inscripción por la revocabilidad de la adopción venezolana; el interesado discrepa sobre el contenido de la ley venezolana y une al recurso fotocopia de la ley venezolana vigente de 18 de agosto de 1983, afirmando la irrevocabilidad de la adopción venezolana, lo que sirvió de base a la D.G.R.N. para estimar el recurso y revocar el acuerdo apelado (favor adoptionis). Téngase en cuenta, también, la Res. DGRN de 9 de septiembre de 2002, sobre inscripción de adopción ecuatoriana, en la que el Juez Encargado del Registro Civil Central denegó la inscripción con base en los arts. 332 y siguientes del Código de Ecuador por ausencia de ruptura con la familia biológica; el interesado discrepa sobre el contenido de la ley ecuatoriana y une al recurso el Código de Menores de 1992, ley actualmente vigente, que establece la ruptura total de vínculos con la familia biológica. La D.G.R.N. estima el recurso, apoyándose tanto en lo aportado por la parte (“...certificación..." del Tribunal de Menores de G., Ecuador, debidamente legalizado por el Consulado de España en Ecuador, que certifica la vigencia del Código de Menores de 1992, así como que son de régimen pleno), como en el “...conocimiento que esta Dirección General tiene de la legislación de la República de Ecuador...”.

Menos éxito tuvo la parte interesada en la Res. DGRN de 20 de enero de 2009, sobre inscripción de adopción constituida en el extranjero, respecto de la solicitud de inscripción de nacimiento de un hijo adoptado en Guinea Bissau, que, denegada por el Juez Encargado del Registro por infracción del art. 1981 de la Ley Guineana, es recurrida ante la D.G.R.N. solicitando la inscripción de nacimiento de su hijo, alegando que "...la calificación está basada en una legislación no vigente actualmente en Guinea-Bissau como es el Código Civil Portugués de 25 de noviembre de 1966, y que hay efectuadas otras adopciones de Guinea Bissau efectuadas por matrimonios de menos de 10 años, y también hay adopciones monoparentales...": la D.G.R.N. desestimó el recurso por infracción de la ley de Guinea-Bissau, sin entrar a valorar una posible sucesión de leyes en el tiempo que tampoco fue aportada por la parte.

Tampoco acostumbra a ser objeto de debate, en fin, la suficiencia de los medios de prueba. Así parece desprenderse de la utilización de la fórmula que ya se ha referido anteriormente de "...de acuerdo con el conocimiento adquirido de la legislación china...”, o “...en vista de las informaciones obtenidas

\footnotetext{
${ }^{73}$ Res. DGRN de 11 de marzo de 1997.
} 
sobre la legislación mexicana...". Hecho que sorprende si se tiene en cuenta la importancia de este aspecto en lo que es la aplicación judicial del Derecho extranjero.

\section{La no determinación de la ley extranjera: consecuencias}

\section{Posibilidad de no-conocimiento}

Si bien en ninguna de las resoluciones que hemos analizado en materia de adopción internacional se ha planteado el problema ${ }^{74}$, lo cierto es que no debemos dejar de lado la posibilidad de que la D.G.R.N. no llegue a conocer el tenor del Derecho extranjero regulador de la adopción constituida por autoridad extranjera.

En efecto, en la totalidad de los casos analizados, la D.G.R.N. ha llegado a conocer el contenido e interpretación de la ley extranjera reguladora de la adopción internacional. Ya vimos como en la mayoría de los supuestos referidos es el propio Juez Encargado del Registro o la D.G.R.N., y no la parte, quien se encarga de traer el Derecho extranjero a la causa a través de los medios de aportación ya relacionados. Recuérdese además que la D.G.R.N. está operando con un sector muy específico del ordenamiento jurídico extranjero, el regulador de las adopciones internacionales, del que ha adquirido conocimiento por haber tratado habitualmente con sus normas dado los países de origen de la mayoría de las solicitudes de inscripción que se interponen en el Registro Civil español, de los que dispone de dossiers muy completos. En otros casos, los menos, es la parte interesada quien se encargó de aportar la normativa extranjera, que posteriormente fue aplicada por los órganos registrales y la D.G.R.N. Piénsese, en esta sede y además, en la flexibilidad de medios que son admitidos, que permiten llegar más fácilmente a un conocimiento de la ley extranjera que la D.G.R.N. entiende como suficiente, a pesar de la peculiaridad de muchas de estas vías.

Ahora bien, lo cierto es que la posibilidad de que la D.G.R.N. no llegue a conocer el tenor del Derecho extranjero regulador de la adopción constituida por autoridad extranjera existe: las adopciones internacionales cada vez son más frecuentes y son más los países que se convierten en Estados receptores de adoptantes, más todavía cuando muchos de ellos son Estados plurilegislativos que disponen cada uno de su propia normativa sobre adopción ${ }^{75}$.

${ }^{74}$ Véanse las resoluciones citadas.

75 Álvarez Álvarez, J.M., "El Registro Civil Central”, B.I.M.J., núm. 1834, de 1 de diciembre de 1998, pp. 3437-3464, espec.p. 3454; CALvo BABío, F., Aplicación judicial del Derecho extranjero..., op . cit., pp. 68-69. Véase, por ejemplo, Res. DGRN de 1 de abril de 1996 (R.E.D.I., 1997-I, p. 256, con nota de Calvo Babío, F.), y Res. DGRN de 16 de septiembre de 1993 (B.I.M.J., 1997, p. 625), en las que la D.G.R.N. debería haber consultado las distintas normativas de los diferentes Estados Federados mexicanos (y no el Código Civil Federal mexicano, que fue lo que hizo, erróneamente). 
Únase a ello el hecho de que, en muchas ocasiones, la lentitud y falta de eficacia y colaboración de los Consulados extranjeros y de las Administraciones Públicas españolas, hecho que afecta tanto a la labor de los órganos registrales como a las partes y de lo que con carácter general se vienen quejando las autoridades registrales españolas, que denuncian que muchas Embajadas y Consulados extranjeros acreditados en España se niegan a expedir certificaciones sobre su legislación a sus propios nacionales, e, incluso, a informar directamente al Juez Encargado del Registro Civil ${ }^{76}$. Tampoco cuentan con instrumentos internacionales que sean realmente eficaces en el práctica, como podía ser el Convenio Europeo de información sobre el Derecho extranjero, de 7 de junio de 1968, ni con organismos como podría ser la Secretaría General Técnica del Ministerio de Justicia, tal vez porque, al no tener asignada esta función de información en exclusiva, no son rápidos en su ejecución, con lo que difícilmente se satisfacen los criterios de economía, celeridad y eficacia requeridos, de acuerdo con lo expuesto en el Preámbulo del Reglamento del Registro Civil, en la tramitación de los expedientes registrales y en las restantes actuaciones del Estado ${ }^{77}$.

\section{Denegación de la solicitud de inscripción}

Pues bien, si se está en un caso de no determinación del contenido de la ley extranjera, lo que en otras sedes y con carácter general suele hacer la D.G.R.N., a diferencia de la práctica en sede judicial, no es la aplicación subsidiaria de la ley española ${ }^{78}$, sino la denegación de la solicitud de inscripción ${ }^{79}$. A nuestro entender, no creemos que la D.G.R.N. vaya a apartarse de esta línea de no inscripción en aquellos casos en los que no consiga llegar a conocer el Derecho extranjero y, con ello, no poder llegar a ponderar la equivalencia de efectos entre la adopción constituida en el extranjero cuya inscripción se solicita y la adopción española (o la aplicación de la ley del adoptando a la capacidad y consentimiento necesarios, como vimos también).

Varios datos avalan la no inscripción como forma de proceder. Por un lado, es lo que parece desprenderse del art. 28 Ley del Registro Civil y del art. 91 Reglamento del Registro Civil, cuando abogan por la paralización del pro-

\footnotetext{
${ }^{76}$ Sobre ello, Alberdi Vecino, F., "Registro Civil y elemento extranjero...,", loc. cit., p. 56; LÓPEZ-BERMEJO MuÑOZ, J., "Evolución estadística de la inmigración y repercusión en el Registro Civil...", loc. cit., p. 94. Específicamente, sobre estos problemas, en materia de adopción, LARA AGUADO, A., “Adopción internacional...”, loc. cit., p. 131.

${ }^{77}$ Sobre este particular, LóPEZ-BERMEJO MuÑOz, J., "Evolución estadística de la inmigración y repercusión en el Registro Civil...", loc. cit., p. 94.

${ }^{78}$ Lara Aguado, A., "Adopción internacional...”, loc. cit., p. 132.

${ }^{79}$ Lara Aguado, A., "Adopción internacional...", loc. cit., p. 132; misma respuesta, con carácter general, FERnÁNDEZ RoZAS, J.C./SÁNCHEZ LORENZO, S., Derecho internacional..., op . cit., 2009, p. 170.
} 
cedimiento hasta la obtención de la documentación requerida, bien del Consulado español en el extranjero, bien del Consulado del Estado al que pertenece la autoridad extranjera que constituyó la adopción ${ }^{80}$. Por otro, el interés del menor en ser integrado en la familia adoptiva no justifica otra forma de comportamiento: el interés del menor en tal sentido cede en estos casos de desconocimiento, ya que no se puede atribuir a una institución extranjera unos efectos que se desconoce si el Derecho del Estado de origen se los atribuye (la no aportación de la ley extranjera unido al hecho de la no intervención de las autoridades administrativas españolas impiden verificar la equivalencia de efectos con la adopción española $)^{81}$. Finalmente, se protegen de este modo los intereses de los padres biológicos del menor: el desconocimiento del Derecho extranjero genera dudas respecto tanto de si la adopción supone la ruptura de vínculos de la familia biológica con el adoptado, como la verificación de la prestación de los consentimientos necesarios de los padres biológicos, requisitos ambos para el reconocimiento de la adopción como plena y equivalente $^{82}$.

En el ámbito registral, pues, no sólo no es extraña la respuesta de no inscripción, sino que, en muchas ocasiones, resulta la mejor opción. Tal como decimos, en ciertos casos, no es posible acudir, en esta sede registral y con carácter general, a la vía de la aplicación subsidiaria de la ley española como sucede en los procedimientos contenciosos. En sede jurisdiccional, la aplicación de la lex fori evita que la aplicación estricta del art. 12.6 Código Civil derive en la ausencia de respuesta sobre el fondo, lo que supondría una vulneración del derecho a la tutela judicial efectiva ${ }^{83}$. En sede registral, por el contrario, esta consecuencia no se produce necesariamente. Lo vemos, por ejemplo, en el caso del Registrador en el Registro Mercantil. La función de una autoridad no judicial como ésta carece del componente constitucional que se halla en los procesos contenciosos, por lo que los motivos de denegación de la inscripción seguirían ubicados en el marco de la legalidad ordinaria: si no se le facilitan a esta autoridad los medios para la averiguación de la ley extranjera, la mejor opción pasaría por la no inscripción, sin que exista tampoco, con carácter general, la obligación de averiguar por sus propios medios la ley extranjera no probada (en este caso, a través de los medios previstos en el art. 36 Reglamento Hipotecario) dado que el art. 281.2 Ley de Enjuiciamiento

\footnotetext{
${ }^{80}$ Así, Álvarez Álvarez, J.M., "El Registro Civil...”, loc. cit., p. 3454.

${ }^{81}$ LARA Aguado, A., “Adopción internacional...", loc. cit., p. 132. También, ArenAS GARCÍA, R., Registro mercantil..., op. cit., p. 423, esta vez en el ámbito del Registro Mercantil, que aboga por la no inscripción ya que no resulta posible admitir al Registro un documento cuya legalidad no ha podido ser contrastada por ausencia de prueba de la ley extranjera.

${ }^{82}$ GuZMÁn ZAPATER, M., "Adopción internacional: ¿cuánto queda del Derecho internacional privado clásico?”, en CAlvo Caravaca, A.L./Iriarte Ángel, J.L., Mundialización y Familia, Madrid, 2001, pp. 112-114.

${ }^{83}$ Garcimartín AlfÉREZ, F.J., Sobre la norma de conflicto..., op. cit., pp. 34-35.
} 
Civil 2000 entiende que la carga de la obligación de probar la normativa extranjera corresponde a la parte interesada. Nada impide, como se indicó antes, que el Registrador decida completar o suplir la falta de actividad probatoria de quien solicita la inscripción ${ }^{84}$, si bien sólo existirá obligación cuando, habiendo presentado la parte elementos de prueba suficientes del contenido del Derecho extranjero, el Registrador estime que no se encuentra suficientemente ilustrado: en este caso, debe ser exigido, antes de rechazar la inscripción, justificación suficiente de este modo de proceder a fin de desautorizar los elementos de prueba ya presentados ${ }^{85}$. La aplicación subsidiaria de la lex fori no parece aquí solución adecuada. En el ámbito judicial, la decisión de un juez tiene efectos entre los litigantes y sus causahabientes (cosa juzgada), de ahí la irrelevancia de la respuesta de la norma de conflicto si ambas partes están de acuerdo en dirimir sus disputas en aplicación de la ley del foro; en el ámbito registral, en cambio, la inscripción tiene efectos frente a quienes no la han solicitado, por lo que no es posible desconocer lo que establece la normativa reguladora de esa inscripción ${ }^{86}$.

Lo expuesto no quiere decir que, en el ámbito registral y en otras situaciones, la opción de la aplicación subsidiaria de la lex fori no pueda ser una opción razonable. Piénsese en algunos Convenios internacionales, que obligan a comportamientos distintos de la no inscripción en casos de imposibilidad de conocimiento de la ley extranjera, como sucede, por ejemplo, con el art. 5 del Convenio de Munich de 5 de septiembre de 1980 sobre ley aplicable a los nombres y apellidos, que establece que "...si el encargado del Registro Civil se encontrase, al extender un acta, en la imposibilidad de conocer el Derecho aplicable para determinar los nombres y apellidos de la persona interesada, aplicará su ley interna e informará al respecto a la autoridad de la que dependa..." 87 . De hecho, cierto sector parece entender, al contrario de lo expuesto, que una respuesta general de aplicación subsidiaria de la ley española se ajustaría mejor a los principios registrales de legalidad y obligatoriedad de la inscripción, y la necesaria concordancia del Registro con la realidad extrarregistral $^{88}$. A nuestro juicio, en cambio y en el ámbito que ahora nos encon-

\footnotetext{
${ }^{84}$ Fernández Rozas, J.C., “Comentario al art. 12.6 C.c.”, en Comentarios..., loc. cit., p. 1077.

${ }^{85}$ Sobre ello, en el ámbito del Registro Mercantil, Arenas GARCía, R., Registro mercantil..., op. cit., p. 424, nota núm. 1154.

${ }^{86}$ ARENAS GARCía, R., Registro mercantil...”, loc. cit., p. 424, en el ámbito del Registro Mercantil; SÁNCHEZ LORENZO, S., "Algunos problemas del régimen jurídico de los actos inscribibles...", loc. cit., p. 2001.

${ }^{87}$ Sobre el particular, Fernández Rozas, J.C./SÁnchez LoRenzo, S., Derecho internacional..., op. cit., 2009, p. 170.

${ }^{88}$ Así lo entiende Alberdi Vecino, F., "Registro Civil y elemento extranjero...", loc. cit., p. 56, que estima que, de no ser así y de no aplicar la ley española, serían muy numerosas las inscripciones denegadas o suspendidas, y tal situación no se ajustaría, a su juicio, a los principios que rigen la ordenación registral española.
} 
tramos de la D.G.R.N. enfrentada a supuestos de inscripción de una adopción internacional, la mejor respuesta resulta, por el contrario, la no inscripción de una adopción constituida ante autoridad extranjera de la que no se saben sus efectos por desconocimiento de la ley extranjera.

Visto lo visto, entendemos, pues, que la mejor opción de la D.G.R.N. en caso de no aportación del Derecho extranjero pasaría por no permitir la inscripción de la adopción.

Se baraja, asimismo, la posibilidad de practicar una anotación con valor simplemente informativo (arts. 38 Ley del Registro Civil; arts. 81, 145 y 154.3 Reglamento del Registro Civil), como si fuese un acogimiento, lo que más tarde permitiría proceder a su conversión como adopción española, o a su constitución ex novo ante las autoridades españolas. Todo ello apelando al interés del menor a ser integrado en la familia de acogida frente a la armonía internacional de soluciones ${ }^{89}$. Con todo, cierto sector advierte del peligro de una práctica generalizada en este sentido, la cual podría volverse en contra del interés del menor: el menor podría adquirir la nacionalidad española por opción, al haber estado sujeto a la patria potestad de un español (art. 20.1 a Código Civil), o adquirirla por residencia por estar sujeto a guarda, tutela o acogimiento de un español (art. 22.2.c Código Civil), pero no podría hacerlo como español de origen ${ }^{90}$.

\section{Conclusiones: algunas consideraciones tras la Ley 54/2007, de 28 de diciembre, de adopción internacional}

\section{Línea continuista}

De las resoluciones que se han analizado y de la exposición de los problemas que la toma en consideración de la ley extranjera plantea a la D.G.R.N., pueden extraerse las siguientes conclusiones.

Por una parte, a pesar de la utilización genérica de los términos de aplicación de la ley extranjera, no se trata propiamente de aplicación en sentido estricto: debería hablarse con mayor propiedad de toma en consideración del Derecho extranjero.

Por otra, esta toma en consideración de la ley extranjera por la D.G.R.N. en materia de adopción presenta pocos puntos de contacto con lo que es la aplicación del Derecho extranjero en el ámbito jurisdiccional.

${ }^{89}$ Esta forma de comportamiento no es extraña a la D.G.R.N., ya que así actuó cuando no existía equivalencia de efectos (p.e.: Res. DGRN de 19 de noviembre de 2005, Boletín Oficial del Estado, 22 de diciembre de 2005), o cuando la ley extranjera prohibía la adopción (p.e.: Res. DGRN de 21 de marzo de 2006, Boletín Oficial del Estado, 30 de mayo de 2006).

${ }^{90}$ Sobre esta cuestiones, LARA AgUADO, A., "Adopción internacional...”, loc. cit., pp. 132133; CANo BAZAGa, E., Adopción internacional y nacionalidad española, Sevilla, 2001, p. 76: EsteBAn DE la Rosa, G. (coord.), Regulación de la adopción internacional..., op. cit., pp. 385-402. 
Primero. No se plantea el problema de a quién corresponde la carga de aportar el Derecho extranjero: aparece más que como un problema como un dato. En muchos casos, es la propia D.G.R.N. quien se encarga de aportar la ley extranjera, y lo hace con base en su propio conocimiento adquirido a partir de diferentes cauces, mientras que el papel de la parte interesada es más residual, a diferencia de lo que sucede en sede judicial.

Segundo. A diferencia de la mayor rigidez en sede jurisdiccional y en consonancia con lo que es la práctica extrajudicial general, los medios a partir de los cuales se aporta el Derecho extranjero resultan múltiples y variados, y, a pesar de sus peculiaridades y gran flexibilidad, no se discute prácticamente nunca su suficiencia.

Tercero. No suele haber discrepancias respecto del contenido de la ley extranjera, cuyo alcance e interpretación viene determinado directamente por parte de la D.G.R.N., esto es, la D.G.R.N. no suele recurrir a la práctica del ordenamiento jurídico de origen a la hora de formarse una idea sobre el alcance de la norma extranjera sobre adopción.

Podría entenderse que esta forma de aproximación a la toma en consideración de la ley extranjera por parte de la D.G.R.N., muchas veces sin poner de manifiesto cómo ha llegado a su conocimiento, o remitiéndose a fuentes escasamente fiables para justificar su contenido, puede llegar a amparar una suerte de indefensión respecto de los participantes en la adopción ${ }^{91}$. Con todo, también es cierto que, en aquellos casos en los que se comprueba una diligencia de la parte en la aportación del Derecho extranjero, se suscita realmente un verdadero debate ${ }^{92}$. Sería, pues, conveniente, dada la actitud reticente o restrictiva de la D.G.R.N. en lo que es la valoración de la posible equiparación de efectos entre adopciones extranjera y española, que la parte interesada asumiese un comportamiento activo respecto del Derecho extranjero (en aquellos casos en los que le es favorable, lógicamente), ya que,

${ }^{91}$ Véase Esteban de la Rosa, G. (coord), Regulación de la adopción internacional..., op. cit., p. 303, nota núm. 103; Calvo BABío, F., Aplicación judicial del Derecho extranjero..., op. cit., p. 68. Así, además de las resoluciones citadas anteriormente, téngase en cuenta la Res. DGRN de 4 de julio de 2005, sobre inscripción de adopción argentina, en la que la D.G.R.N. deniega el reconocimiento de una adopción constituida en Argentina por su carácter de adopción simple y por ausencia de equivalencia de efectos, y ello sin manifestar cuáles fueron sus fuentes a la hora de llegar al conocimiento del Derecho de ese Estado. También, Res. DGRN de 1 de abril de 1996 (R.E.D.I., 1997-I, p. 256, con nota de Calvo Babío, F.), y Res. DGRN de 16 de septiembre de 1993 (B.I.M.J., 1997, p. 625), donde la D.G.R.N., a la hora de ponderar los efectos entre la adopción mexicana y la española, lo hace sin comprobar de qué Estado Federado de México proviene la adopción, consultando erróneamente el Código Civil Federal mexicano y no las concretas legislaciones de los Estados Federados que lo componen.

${ }^{92}$ Véanse las referidas Res. DGRN de 11 de marzo de 1997, sobre inscripción de adopción venezolana; Res. DGRN de 9 de septiembre de 2002, sobre inscripción de adopción ecuatoriana; Res. DGRN de 21 de febrero de 2007, sobre inscripción de adopción etíope. 
cuando así lo hizo, la actitud de la Dirección General fue totalmente receptiva. De hecho, aquellos casos en los que la D.G.R.N. no fue receptiva a las alegaciones de la parte interesada basadas en una ley extranjera, tienen mucho que ver con el hecho de la pasividad de la parte a la hora de traer prueba de lo que ésta última entendía como ley extranjera vigente, en la que se basaba su recurso frente a lo estimado por el Juez Encargado del Registro y de la que no aportó ni norma ni práctica propia del Estado de origen que refrendase su alegación ${ }^{93}$.

Cuarto. Aunque en la práctica analizada no se ha planteado, no debe descartarse aquella situación de imposibilidad de determinación de la ley extranjera por parte de la D.G.R.N.: de ser así, ello conducirá, más que a la aplicación subsidiaria de la ley española, a la no inscripción de la resolución extranjera constitutiva de la adopción.

En fin, en lo expuesto, téngase en cuenta un dato más. Las conclusiones extraídas son representativas sólo de una parte muy concreta de la problemática relativa a la aplicación extrajudicial del Derecho extranjero, esta vez, la que se corresponde con la labor de la D.G.R.N. respecto de sus últimas resoluciones sobre adopción internacional anteriores y posteriores a la entrada en vigor de la Ley 54/2007, de 28 de diciembre, de adopción internacional. En ausencia de un análisis más amplio y general de todo el sector, su parcialidad justifica la inconveniencia de extender estas conclusiones a otras parcelas de la realidad internacional que llega al Registro, todo ello, siendo conscientes de la necesidad de proporcionar una respuesta general a toda esta problemática, que contribuya a paliar, de alguna manera, el déficit doctrinal existente.

\section{Expectativas de futuro}

A nuestro entender, las conclusiones expuestas, aun cuando extraídas de una práctica mayoritaria nacida bajo la regulación anterior, mantienen su vigencia en la actualidad, una vez entrada en vigor de la la Ley 54/2007, de 28 de diciembre, de adopción internacional.

En efecto, la D.G.R.N. parece (querer) mantener una línea de continuidad con la práctica anterior respecto de lo que es la ley extranjera en sus resoluciones relativas a adopción internacional. Resoluciones emitidas al amparo de la nueva Ley, no muy abundantes a día de hoy, se enfrentan a la ley extranjera en términos parecidos a los empleados hasta el momento por la D.G.R.N., tal como sucede, como vimos y por ejemplo, en la Res. DGRN de 26 de febrero de 2010, de adopción internacional. No extraña este comportamiento si observamos la práctica reciente inmediatamente anterior a la entrada en vigor de la normativa vigente: en muchas de sus resoluciones de estos

\footnotetext{
${ }^{93}$ Véase la Res. DGRN de 20 de enero de 2009, sobre inscripción de adopción constituida en el extranjero.
} 
últimos años, aunque referidas a expedientes nacidos al amparo de la regulación anterior, la D.G.R.N., tal como dijimos, viene introduciendo aspectos de la nueva regulación de la Ley 54/2007, de 28 de diciembre, de adopción internacional, especulando con lo que, en hipótesis, sería su aplicación de regular el caso ${ }^{94}$; y en estos casos no observamos comportamientos diferentes en cuanto al trato que le dispensa a la ley extranjera, con lo que no parece que vaya a haber un después tras la aplicación de la Ley 54/2007, de 28 de diciembre, de adopción internacional. Por ello no creemos que la D.G.R.N. varíe, con carácter general, su forma de enfrentarse a una ley extranjera en aquellas resoluciones de adopción plenamente sometidas al imperio de la nueva normativa. Piénsese, además, que la nueva regulación no sólo nada dice al respecto, sino que vuelve a plantear la toma en consideración de la ley extranjera en casi las mismas sedes que la regulación anterior.

Con todo, y a pesar de la línea continuista descrita, entendemos que la nueva Ley 54/2007, de 28 de diciembre, de adopción internacional, puede alterar ciertos aspectos de lo expuesto.

A nuestro juicio, cabe la posibilidad de que la nueva Ley 54/2007, de 28 de diciembre, de adopción internacional plantee situaciones que, en la práctica, generen mayores dificultades a la hora de conocer el Derecho extranjero. Sirva el caso, por ejemplo, del art. 26.1 LAI 2007. Frente al anterior art. 9.5 Código Civil, que exige la verificación de que la autoridad extranjera que constituyó la adopción haya aplicado la ley del adoptando a su capacidad y consentimiento necesarios, el art. 26.2 LAI 2007 exige verificar que la autoridad extranjera haya constituido la adopción según el Derecho estatal designado por las normas de conflicto del Estado del que depende esta Autoridad extranjera. O, lo que es lo mismo, habrá que conocer no sólo el Derecho material extranjero, sino también si la autoridad extranjera aplicó correctamente su norma de conflicto. Y ello puede presentar una gran complicación, porque sí ya lo es conocer el tenor de una normativa ajena, tanto material como conflictual, más lo será llegar a conocer, sobre todo en el segundo de los casos, cómo el operador jurídico extranjero se enfrenta a la aplicación de la ley extranjera a la que remite su propia norma de conflicto ${ }^{95}$.

\footnotetext{
${ }^{94}$ Véase, por ejemplo, la Res. DGRN de 21 de octubre de 2008, sobre inscripción de adopción.

${ }_{95}$ Arenas García, R./González Beilfuss, C., "La Ley 54/2007, de 28 de diciembre, de Adopción Internacional: entre la realidad y el deseo", en www.reei.org, par. 36, que señalan las dificultades prácticas que implica un control como el referido, de difícil realización, dado que va a exigir traer al procedimiento de reconocimiento en España las normas de conflicto extranjeras, así como el Derecho al que se remitan; así, entienden que “...dadas las dificultades que plantea en general la prueba del Derecho extranjero y lo escaso de su aplicación por nuestros Tribunales, esta exigencia ha de valorarse como desproporcionada; sobre todo si tenemos en cuenta que (...) podría ser que tal falta de aplicación del Derecho extranjero aplicable no supusiera, de acuerdo con el ordenamiento extranjero de la autoridad que ha constituido la adopción, la posterior nulidad de ésta...”. En el mismo sentido, ÁLVAREZ GON-
} 
Ilustrativo de ello es la Res. DGRN de 6 de marzo de 1997, sobre inscripción de adopción china, aunque sea de un caso anterior a la Ley 54/2007, de 28 de diciembre, de adopción internaciona ${ }^{96}$. Se pretendía la inscripción de adopción constituida en China por padres vietnamitas y ahora españoles. El Juez Encargado del Registro Civil Central denegó la inscripción por revocabilidad de la adopción china, a lo que se opusieron los adoptantes. La D.G.R.N. denegó la inscripción de la adopción en el Registro civil español, si bien no lo hizo a partir de la valoración de la revocabilidad o no de la adopción china, sino porque, a su juicio, no se respetaron las exigencias del Derecho chino (algo que, en aquellos momentos, no era un control exigido por el legislador español), esto es, es la D.G.R.N. la que realiza una valoración (negativa) de la aplicación del Derecho chino por las propias autoridades chinas. Y esto es lo que debería llamarnos la atención: ante una adopción realizada en China y cuya corrección fue certificada por la Sección Consular de la Embajada de China en España, la D.G.R.N. efectuó un control de la competencia de las autoridades chinas desde su propia ley (“...ley china del adoptando que debería regir en cuanto a la autoridad competente"), un control sobre la forma y sobre la necesidad de inscripción (de acuerdo con el Derecho chino) y denegó la inscripción de la adopción en el Registro civil español. En el expediente se había aportado un certificado de parentesco expedido por la Sección Consular de la Embajada china acreditando que, de acuerdo con el Derecho chino, el adoptando era hijo adoptivo de los adoptantes. Sin embargo, como decíamos, la D.G.R.N. corrigió lo dicho por la Embajada y estimó que la adopción no se había constituido por incumplimiento de las exigencias del Derecho chino (carecer de inscripción en el Registro Civil chino). O, lo que es lo mismo, aplicando el Derecho chino, la D.G.R.N. pasa por encima de lo dispuesto en el certificado de parentesco expedido por la Embajada de China en España.

ZÁLEZ, S., "El Proyecto de ley sobre adopción internacional: una crítica para sobrevivir a su explicación docente", Actualidad Civil, 2007, pp. 2597-2618, espec. pár. 19, cuando, apelando a las dificultades que existen en la práctica real actual respecto de la aplicación del Derecho extranjero por parte de Tribunales y autoridades españolas, entiende que “...si resulta difícil la cultura del Derecho extranjero reclamado por nuestras normas de conflicto, ¿qué puede decirse del Derecho reclamado por las normas de conflicto de un ordenamiento extranjero?...". Véase, por el contrario, Calvo Caravaca, A.L./CARrascosa GonzÁlez, J., La Ley 54/2007, de 28 de diciembre 2007 sobre adopción internacional. reflexiones y comentarios, Granada, 2008, pp. 196-197, que estiman que el Derecho reclamado por la norma de conflicto extranjera no debe ser controlado, algo con lo que no están de acuerdo ARENAS GARCíA, R./GonZÁleZ BeIlfuss, C., "La Ley 54/2007, de 28 de diciembre, de Adopción Internacional...", loc. cit., nota núm. 59, ni Álvarez GonZÁlez, S., "El Proyecto de ley sobre adopción internacional...", loc. cit., pár. 19.

${ }^{96}$ Una crítica a esta forma de comportamiento que la D.G.R.N. manifestó en esta resolución, puede verse en ÁLvAREZ GonZÁLEZ, S., "El Proyecto de ley sobre adopción internacional...", loc. cit., pár. 19. 
En todos estos casos, llegar a conocer el Derecho extranjero va a exigir un mayor esfuerzo por parte de la D.G.R.N., del Ministerio Fiscal o de los interesados. En esta labor, recuérdense, amén de la poca eficacia en lo que es la información de la ley extranjera que se le achaca a organismos como la Secretaría General Técnica del Ministerio de Justicia, las quejas de los órganos registrales relativas a la lentitud y falta de eficacia y colaboración de los Consulados extranjeros y de las Administraciones Públicas españolas, denunciando la negativa de muchas Embajadas y Consulados extranjeros acreditados en España a expedir certificaciones sobre su legislación a sus propios nacionales, e, incluso, a informar directamente al Juez Encargado del Registro Civil ${ }^{97}$.

Hasta el momento, la D.G.R.N. se ha desenvuelto con soltura en su faceta de averiguación de la ley extranjera en materia de adopción internacional, sobre todo, como vimos antes, por su propia especialización, reflejada en los dossiers que elabora relativos a la ley extranjera, además de las fichas de información sobre los países de origen que aparecen en las páginas web de los distintos Ministerios o Gobiernos autonómicos, facilitado por el hecho de que muchas de las adopciones provengan de los mismos países ${ }^{98}$. No obstante, las mayores dificultades que pueden surgir de la aplicación de la nueva normativa de adopción internacional, específicamente, así como, y ya con carácter general, la necesidad de acceso a un número mayor de leyes extranjeras por las particularidades sociales del momento actual ${ }^{99}$, aconsejarían, como se viene exigiendo desde ciertas opiniones, la adopción de una serie de medidas, no sólo en el marco del Registro Civil, sino también desde los ámbitos competenciales de las distintas autoridades no judiciales, a la hora de facilitar el acceso al conocimiento del contenido e interpretación de aquellas leyes extranjeras a las que se tienen que enfrentar por ministerio de la ley.

Amén de la utilización de los cauces que la normativa convencional o autónoma ofrecen al operador jurídico, las posibilidades que se han barajado para mejorar el sistema de información de la ley extranjera son varias. Por una parte, creación de un base de datos propia del Registro Civil, que agrupase las resoluciones de la D.G.R.N., toda la legislación aplicable, formularios y artículos doctrinales ${ }^{100}$, al margen de las bases propias que vayan

${ }^{97}$. LARA Aguado, A., “Adopción internacional...”, loc. cit., p. 131. En general, AlbeRdi Vecino, F., "Registro Civil y elemento extranjero...", loc. cit., pp. 55-56.

${ }^{98}$. LaRa Aguado, A., "Adopción internacional...", loc. cit., p. 132; VAn LoON, J.H.A., "Report on Intercountry Adoption", Hague Conference on Internacional Private Law, abril 1990, anexo C, pp. 11-31.

99. LÓPEZ-BERMEJO MuÑOZ, J., "Evolución estadística de la inmigración y repercusión en el Registro Civil...”, loc. cit., pp. 88 y 92-95; BlanCo-Morales LimOnes, P./CABAllud HerNANDO, A., "Inmigración y Registro Civil...”, loc. cit., pp. 1272 y 1298-1299.

${ }^{100}$. LÓPEZ-BERMEJO MUÑOZ, J., "Evolución estadística de la inmigración y repercusión en el Registro Civil...", loc. cit., p. 132. 
creando, por el discurrir de su labor, las distintas autoridades no judiciales, como hace la D.G.R.N. para sus casos de adopción internacional. Por otra, y lo que es más importante, creación de un organismo especializado para informar de forma rápida y eficaz sobre el contenido del Derecho extranjero ${ }^{101}$, así como la creación por parte de la Administración de un organismo de información legislativa internacional que atendiese a consultas oficiales a través de Internet, fax, teléfono, con respuestas en tiempo razonable. Todo ello, dentro de un contexto en el que se facilite el intercambio de información jurídica y cooperación en expedientes entre los distintos Registros Civiles, Registros Civiles Consulares, y Registro Civil Central, vía fax, Internet, teléfono ${ }^{102}$.

Piénsese que, con los medios actuales y una correcta actitud de colaboración entre las distintas entidades implicadas, los distintos Ministerios, con carácter particular, el Ministerio de Justicia, en apoyo tanto de jueces y Tribunales, como de los operadores jurídicos y autoridades extrajudiciales, debería derivar en un acceso cada vez más seguro y eficaz a las leyes extranjeras ${ }^{103}$. Téngase en cuenta, en este sentido, medios como Internet, que pueden facilitar información sobre ordenamientos jurídicos extranjeros a través de páginas web correctamente supervisadas por las autoridades competentes, de posibles certificaciones de Derecho extranjero por autoridades estatales, debidamente identificadas electrónicamente y que intercambien información sistematizada y fiable en el espacio virtual ${ }^{104}$.

Con ello se conseguiría un acceso rápido, eficaz y fiable, al contenido de la ley extranjera en los casos en los que la norma así lo exigiese, lo que contribuiría a eliminar las reticencias del operador jurídico a la hora de enfrentarse a una normativa que no es la propia, así como reforzar la garantía del principio de seguridad jurídica y tutela del justiciable. Hasta ese momento, que esperamos no lejano, las autoridades judiciales y no judiciales, como la D.G.R.N., deberán seguir contando con los cauces tradicionales, además del bagaje extraído de su propia labor.

101. LARA AguAdo, A., “Adopción internacional...”, loc. cit., pp. 131-132: LóPEZ-BERMEjo MuÑoz, J., "Evolución estadística de la inmigración y repercusión en el Registro Civil...", loc. cit., pp. 94 y 132.

102. LÓPEZ-BERMEJO MUÑOZ, J., "Evolución estadística de la inmigración y repercusión en el Registro Civil...", loc. cit., p. 132.

103 . Véase Espiniella MenÉndeZ, A., en "Nota a STC 172/2004, de 18 de octubre", R.E.D.I., vol. LVII, 2005-I, p. 344, aunque en el ámbito judicial; también, DE MiguEL AsENSIO, P.A., "El Derecho internacional privado ante la globalización", Anuario Español D.i.pr., 2001-I, pp. 37-87, espec. p. 84.

${ }^{104}$. LÓPEZ-BERMEJO MUÑOZ, J., "Evolución estadística de la inmigración y repercusión en el Registro Civil...”, loc. cit., p. 132, en el ámbito del Registro. 


\section{Bibliografía}

Alberdi Vecino, F., "Registro Civil y elemento extranjero. Problemática en cuanto a la ley aplicable", en Registro Civil: incidencia del fenómeno de la inmigración, Cuadernos de Derecho Civil, 2004, pp. 39-81.

Álvarez Álvarez, J.M., "El Registro Civil Central”, B.I.M.J., núm. 1834, de 1 de diciembre de 1998, pp. 3437-3464.

Álvarez GonZÁlez, S., "Adopción internacional y sociedad multicultural”, Cursos de Derecho internacional privado de Vitoria Gasteiz, 1998, pp. 177-211.

-, "Aplicación judicial del Derecho extranjero: la desconcertante práctica judicial, los estériles esfuerzos doctrinales y la necesaria reforma legislativa", La Ley, 4 de julio de 2005, pp. 1-7.

-, "Dos cuestiones de actualidad en el reciente Derecho internacional privado español de sucesiones: los derechos del cónyuge supérstite y el reenvío", Homenaje al Prof. F.J. Serrano García, Universidad de Valladolid, 2004, pp. 131-158.

_, "El Proyecto de ley sobre adopción internacional: una crítica para sobrevivir a su explicación docente", Actualidad Civil, 2007, pp. 25972618.

- "Igualdad, competencia y deslealtad en el sistema español de Derecho interregional (y en el de Derecho internacional privado)", R.E.D.I., 2001, pp. 49-74.

AREnas GaRCÍA, R., Registro mercantil y Derecho del comercio internacional, Madrid. 2000.

Arenas García, R./González Beilfuss, C., "La Ley 54/2007, de 28 de diciembre, de Adopción Internacional: entre la realidad y el deseo", en www.reei.org,

Blanco-Morales Limones, P./Caballud Hernando, A., "Inmigración y Registro Civil”, B.I.M.J., núm. 2059, 2008, pp. 1271-1299.

BORRÁs RODRíGUEZ, A., "El interés del menor como factor de progreso y unificación", Revista Jurídica de Catalunya, 1994, pp. 915-992.

Calvo Babío, F., Reconocimiento en España de las adopciones simples realizadas en el extranjero, Madrid, 2003.

-, Aplicación judicial del Derecho extranjero en materia de familia, Valencia, 2010.

Calvo Caravaca, A.L., “Art. 9.8 C.c.”, Comentarios al Código civil y Compilaciones forales, $2^{\mathrm{a}}$ ed., Madrid, 1995, pp. 350-391.

Calvo Caravaca, A.L./Carrascosa González, J., Derecho de familia internacional, $2^{\mathrm{a}}$ ed., 2004.

—, La Ley 54/2007, de 28 de diciembre 2007 sobre adopción internacional. Reflexiones y comentarios, Granada, 2008.

Carballo PiñEIRo, L., "El carácter imperativo de la norma de conflicto y la prueba del Derecho extranjero. Una relectura en clave procesal y constitucional”, Anuario español D.i.pr., vol. I, 2001, pp. 485-504. 
Carrillo Pozo, L., "El Derecho extranjero en el proceso de trabajo", Rev. Min. Trab. y Asuntos Soc., núm. 62, 2006, pp. 13-57.

Carrillo Salcedo, J.A., “Art. 12.6 C.c.”, en Comentarios al Código Civil y Compilaciones Forales, M. AlBALAdEJo (dir.) Jaén, 1978, pp. 445-450.

Castellanos Ruiz, E., Unidad vs. pluralidad legal de sucesión internacional, Granada, 2001.

Cortés Domínguez, V., Derecho procesal civil internacional, Madrid, 1981.

Cuartero Rubio, M.V., "Prueba del Derecho extranjero y tutela judicial efectiva", Derecho Privado y Constitución, $\mathrm{n}^{\circ}$ 14, 2000, pp. 21-71.

De Miguel Asensio, P., "El Derecho internacional privado ante la globalización", A.E.D.i.pr., 2001-I, pp. 37-87.

Esteban DE LA Rosa, G. (coord), Regulación de la adopción internacional (nuevos problemas, nuevas soluciones), 2007.

FERnÁndez RozAS, J.C., "Comentario al art. 12.6 C.c.", en Comentarios al Código Civil y Compilaciones Forales, M. Albaladejo/S. DíAz AlabarT (dir.), tomo I, vol. II, Edersa, Madrid, 1995, pp. 973-1082.

-, "La aplicación del Derecho extranjero por los notarios", en Conferencia pronunciada en la Academia Matritense del Notariado el día 17 de diciembre de 1994, Anales de la Academia Matritense del Notariado, tomo XXXV, Madrid, pp. 175-209.

FERnÁNDEZ RozAs, J.C./SÁNCHEZ LORENZO, S., Derecho internacional privado, $5^{\mathrm{a}}$ ed., Madrid, 2009.

Garcimartín Alférez, F.J., Sobre la norma de conflicto y su aplicación judicial, Tecnos, Madrid, 1994.

González CAmpos, J.D. (et al.), Derecho internacional privado. Parte especial, Eurolex, Madrid, 1995.

GuZMÁn ZAPATER, M., “Adopción internacional: ¿cuánto queda del Derecho internacional privado clásico?”, en A.L. CALVO CARAVACA/J.L. IRIARTE Ángel, Mundialización y Familia, Madrid, 2001, pp. 112-114.

Herranz Ballesteros, M., El interés del menor en los Convenios de la Conferencia de La Haya de Derecho Internacional Privado, Valladolid, 2004.

JimÉNEZ BlanCo, P., “Art. 281 LEC 2000”, Ley de Enjuiciamiento Civil (Ley 1/2000), F. Gómez de Liaño (coord.), Oviedo, 2000, pp. 348-350.

LARA AguAdo, A., "Adopción internacional: relatividad de la equivalencia de efectos y sentido común en la interpretación del Derecho extranjero", R.E.D.I., vol. LX, 2008-I, pp. 128-145.

LÓPEZ-BERMEJO MuÑoz, J., "Evolución estadística de la inmigración y repercusión en el Registro Civil", en Registro Civil: incidencia del fenómeno de la inmigración, Cuadernos de Derecho Civil, 2004, pp. 83-132.

MASEDA RodrígueZ, J. "La toma en consideración del Derecho extranjero por la D.G.R.N. en materia de adopción internacional", en Derecho registral internacional. Homenaje a la memoria del Profesor Rafael Arroyo Montero, Iprolex, Madrid, 2003, pp. 351-360. 
—, "La interpretación judicial del Derecho extranjero", Rev. Der. Privado, 1997, pp. 793-822.

- , "La aplicación judicial del Derecho extranjero: el nuevo régimen de la LEC y la reciente jurisprudencia del Tribunal Constitucional", Actualidad Civil, núm. 12, 2002, pp. 413-446.

Molíns García-ATANCE, E., "La aplicación de la ley extranjera por los Tribunales españoles y la posición que debe adoptar el juez en estos procesos", en Objeto y carga de la prueba civil, J. Pico I JUNOY/X. ABEL LluCH, 2007, pp. 277-300.

Rodríguez Gayán, E., Derecho registral civil internacional, Eurolex, Madrid, 1995.

SÁNCHEZ LORENZO, S. "Globalización, pluralidad cultural y Derecho internacional de la familia", Anuario Hispano-Luso-Americano de Derecho Internacional, núm. 17, Madrid, 2005, pp. 87-130.

- "Algunos problemas del régimen jurídico de los actos inscribibles relativos a ciudadanos británicos", Revista Crítica de Derecho Inmobiliario, 2006, pp. 1999-2015.

VAN LoON, J.H.A., "Report on Intercountry Adoption”, Hague Conference on Internacional Private Law, abril 1990, anexo C, pp. 11-31.

Virgós Soriano, M./Garcimartín AlfÉRez, F.J. Derecho procesal civil internacional (litigación internacional), Civitas, Madrid, 2000.

-, Derecho procesal civil internacional (litigación internacional), $2^{\mathrm{a}}$ ed., Civitas, Madrid, 2007. 